The Effects of Alkalinity, Hardness, and $\mathrm{pH}$ on the Formation Potential of Disinfection By-Products

\begin{tabular}{|c|}
\hline A Thesis \\
\hline Presented to \\
\hline The Faculty of the Graduate School \\
\hline At the University of Missouri-Columbia \\
\hline In Partial Fulfillment \\
\hline Of the Requirements for the Degree \\
\hline Master of Science \\
\hline by \\
\hline Dan David \\
\hline Dr. Enos Inniss, Thesis Supervisor \\
\hline July 2014 \\
\hline
\end{tabular}


The undersigned, appointed by the dean of the Graduate School, have examined the

Thesis entitled

\title{
The Effects of Alkalinity, Hardness, and pH on the Formation Potential of Disinfection By-Products
}

\author{
presented by Dan David, \\ candidate for the degree of Master of Science, \\ and \\ hereby certify that, in their opinion, is worthy of acceptance.
}

Enos Inniss, Ph.D

Kathleen Trauth, Ph.D

Allen Thompson, Ph.D 


\section{ACKNOWLEDGEMENTS}

I would like to thank Dr. Inniss for serving as my thesis advisor, and for providing valuable support that made the completion of this thesis possible. Special thanks are given to Dr. Trauth and Dr. Thompson for participating in my committee.

This thesis would not have been possible without the encouragement from my colleagues and friends, I would also like to thank Si Shen, Shiyi Wang, JingJing Dai, and Michael Schoelz for their assistance in helping set up and run these experiments.

Finally, I wish to thank Connie Taylor for all the support she has given me throughout this semester. 


\section{TABLE OF CONTENTS}

Chapter

Page

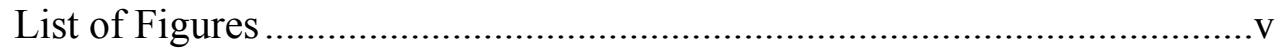

List of Tables .......................................................................................... vi

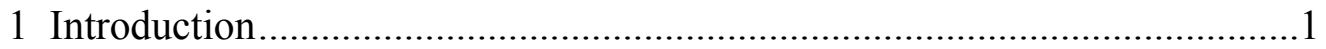

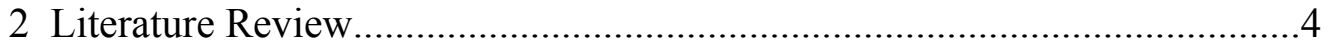

2.1 Chlorine / Chloramines as Disinfectants.....................................8

2.2 Disinfection By-Products1 ......................................................... 13

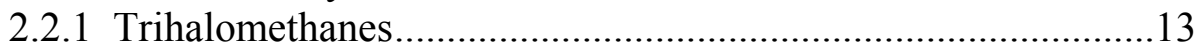

2.2.2 Haloacetic Acids ..............................................................14

2.3 Treatment Processes..................................................................15

2.3.1 Pre-Oxidation....................................................................... 16

2.3.2 Carbon Adsorption...................................................................16

2.3.3 Biofiltration (i.e. Biologically Active) ..................................17

2.3.4 Enhanced Coagulation .......................................................18

2.3.5 Chlorination Point ................................................................... 18

2.3.6 pH Adjustment .......................................................................20

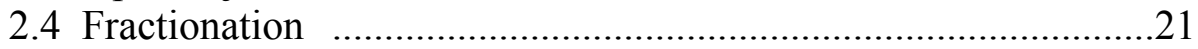

2.5 Environmental factors of Source Water on BMPs......................22

2.5.1 Commonly Found Compounds as NOM .............................. 24

2.5.2 Alkalinity ..................................................................... 24

2.5.3 Hardness ....................................................................... 25

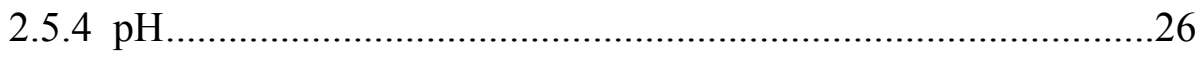

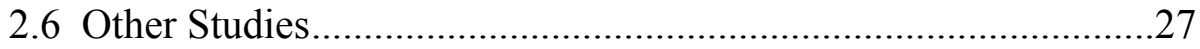

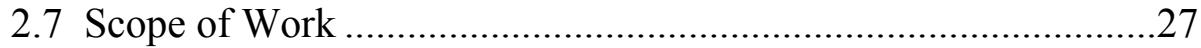

3 Methodology and Experimental Design ...................................................29

3.1 Typical Water Quality Estimation .............................................29

3.2 Variable Water Quality Experimental Plan ...............................30

3.3 Making Synthetic Water ...........................................................32

3.4 Dosing Water with Fractionation Component ..............................32

3.5 Analytical Procedures ...............................................................33

3.5.1 Chlorine Demand .................................................................33

3.5.2 Disinfection By-Product Formation Potential Kinetics .............33

3.5.3 TOC, UV-254, SUVA, and Turbidity.....................................34

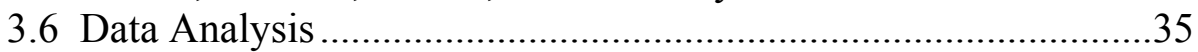

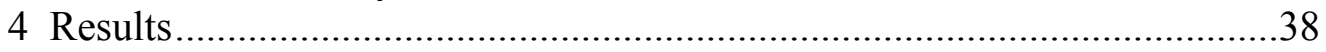

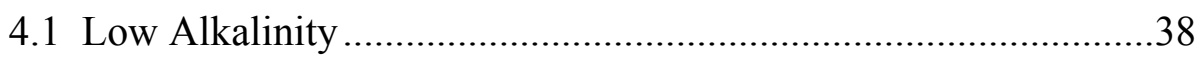

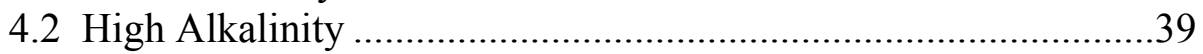

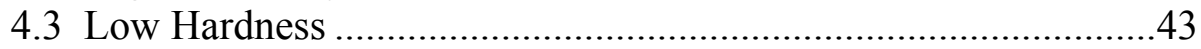

4.4 High Hardness....................................................................44

4.5 Global Mean Value ................................................................47

4.6 Surrogate Parameter Considerations.........................................49 


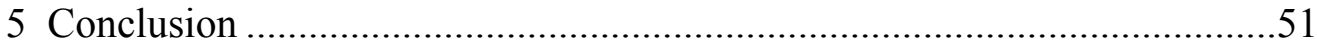

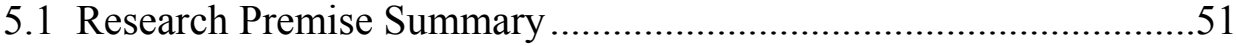

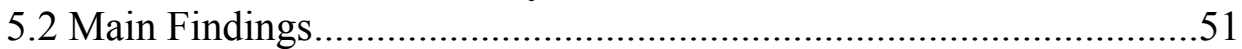

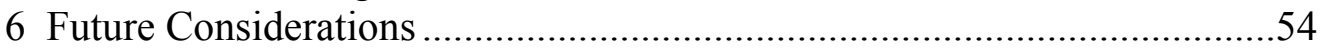

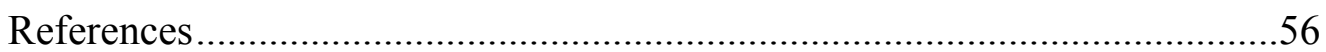




\section{LIST OF FIGURES}

FIGURE

PAGE

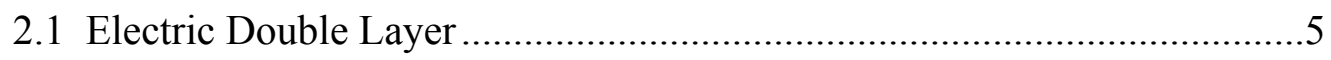

2.2 Overview of membrane separation by membrane type ..............................6

2.3 Breakpoint Chlorination curve ................................................................10

2.4 Molecular structure of methane and four regulated trihalomethanes .......14

2.5 Molecular Structures of acetic acid and nine haloacetic acids .................14

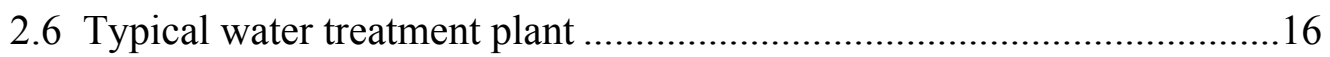

2.7 Rate of DBP Formation based on contact time........................................19

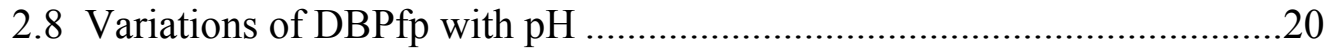

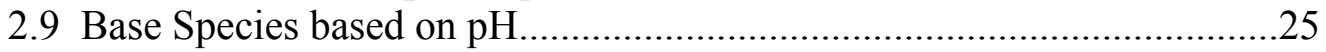

4.1 TTHMfp under Low Alkalinity $\left(100 \mathrm{mg} / \mathrm{L}\right.$ as $\left.\mathrm{CaCO}_{3}\right)$ conditions - All pH ranges........................................................................................39

4.2 TTHMfp under High Alkalinity $\left(155 \mathrm{mg} / \mathrm{L}\right.$ as $\left.\mathrm{CaCO}_{3}\right)$ conditions

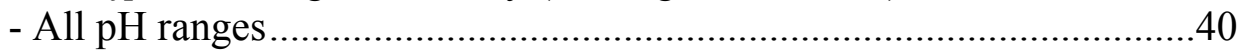

4.3 TTHMfp under Low and High Alkalinity conditions,

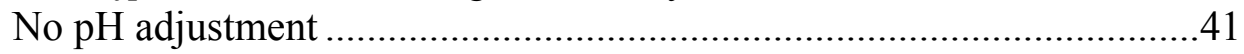

4.4 TTHMfp under Low and High Alkalinity conditions, $\mathrm{pH} 7.5$

4.5 TTHM fp under Low and High Alkalinity conditions, $\mathrm{pH} 8.75$

4.6 TTHMfp under Low and High Alkalinity conditions, $\mathrm{pH} 10.0$

4.7 TTHM $f p$ under Low Hardness $\left(100 \mathrm{mg} / \mathrm{L}\right.$ as $\left.\mathrm{CaCO}_{3}\right)$ conditions - All $\mathrm{pH}$ ranges.

4.8 TTHMfp under High Hardness $\left(160 \mathrm{mg} / \mathrm{L}\right.$ as $\left.\mathrm{CaCO}_{3}\right)$ conditions

- All $\mathrm{pH}$ ranges

4.9 TTHMfp under Low and High Hardness conditions,

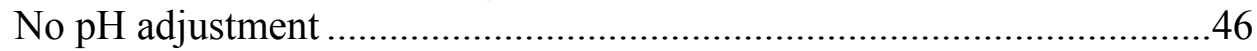

4.10 TTHMfp under Low and High Hardness conditions, $\mathrm{pH} 7.5$.

4.11 TTHMfp under Low and High Hardness conditions, $\mathrm{pH} 8.75$

4.12 TTHM $f p$ under Low and High Hardness conditions, $\mathrm{pH} 10.0$

4.13 TTHMfp under Global Mean Value (Hardness at $100 \mathrm{mg} / \mathrm{L}$ and Alkalinity at $155 \mathrm{mg} / \mathrm{L}$ as $\mathrm{CaCO}_{3}$ ) conditions - $\mathrm{All} \mathrm{pH}$ ranges 


\section{LIST OF TABLES}

Table

2.1 Water hardness levels concentration in $\mathrm{mg} / \mathrm{L}$ as $\mathrm{CaCO}_{3} \ldots \ldots \ldots \ldots \ldots \ldots \ldots . . . . . . . . . .26$

3.1 Global water parameters used for synthetic water determination..............30

3.2 Experiment water parameters ........................................................ 31

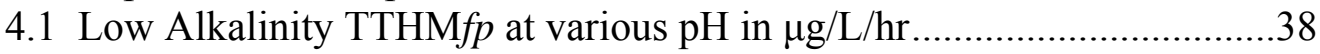

4.2 High Alkalinity TTHMfp at various $\mathrm{pH}$ in $\mu \mathrm{g} / \mathrm{L} / \mathrm{hr}$.............................39

4.3 Low Hardness TTHMfp at various $\mathrm{pH}$ in $\mu \mathrm{g} / \mathrm{L} / \mathrm{hr}$................................43

4.4 High Hardness TTHMfp at various $\mathrm{pH}$ in $\mu \mathrm{g} / \mathrm{L} / \mathrm{hr}$...............................44

4.5 Global Mean Values TTHMfp at various $\mathrm{pH}$ in $\mu \mathrm{g} / \mathrm{L} / \mathrm{hr}$........................48

5.1 Concentrations $(\mu \mathrm{g} / \mathrm{L})$ of TTHMs after 72 hour Incubation Period...........51

6.1 UV Wavelength Absorption Peaks for a Given Substance.......................55 


\section{CHAPTER 1 INTRODUCTION}

Human survival is dependent upon the availability of clean, fresh water. The availability of fresh water should not be a concern as the planet is 70 percent water. However, of this vast amount of water, 97 percent is in oceans and seas and is unfit to drink without expensive treatment, and two percent is locked up in the polar icecaps and ice sheets and is virtually unavailable. The last one percent is located across the globe in lakes, rivers, and ground water (US Department of the Interior, 2014).

As the world's population continues to increase, the amount and availability of fresh water is declining. Approximately two thirds of the world's population does not have access to this resource, and what is available may be contaminated to such an extent that drinking the water would cause severe illness. Waterborne illness has been documented throughout history even though the science of the Dark Ages believed the bad or corrupt air caused sickness (Steiner, 2007). One of the most noted cases of waterborne disease outbreaks happened in 1855 in London, England where an outbreak of cholera caused an epidemic in the city. Dr. John Snow, an epidemiologist, investigated the problem and discovered the neighborhood used a common well to obtain his or her drinking water, and everyone who became ill could be traced to using the Broad Street well. Upon further investigation, it was discovered the dwellings around the well used the basements of the buildings for wastewater collection, and these septic tanks were 
leaking into the nearby well. Dr. Snow removed the pump handle from the well and, thus, practically ended the epidemic overnight (The Science Museum, 2004).

The United States Environmental Protection Agency (USEPA) designates drinking water systems as community and non-community. A community water system serves year-round residents (an average of 25 or more persons or 15 or more service connections). A non-community system can serve transients or nontransients; transient systems serve persons at campgrounds, motels, gas stations, or other businesses that have their own water supply and non-transient systems regularly serves 25 or more of the same persons for at least six months of the year. An example of a non-transient system may be schools, hospitals, or a factory (USEPA, 2012).

During the time span from 1920 to 2002 there were at least 1,870 waterborne disease outbreaks (WBDO) in the United States, an average of 22.5 per year (Craun, M.F et al, 2006). In the most recent 12-year period (1991 2002), 207 WBDO and 433,947 illnesses were reported. Of these, 42 percent were from non-community systems; 36 percent from community systems; and the last 22 percent were from individual systems i.e. private wells. WBDO in community systems range from 247 to 5714 illnesses per outbreak and in non-community systems WBDO ranged from 51 to 268 illnesses per outbreak (Craun, M.F et al, 2006)

In what may be the largest outbreak in recent history, in 1993 a WBDO in the city of Milwaukee, Wisconsin reported over 433,000 illnesses and 50 deaths. A study of the mortality during the outbreak listed cryptosporidiosis as the 
contributing cause of death for these WBDO associated deaths. Only four deaths were expected (Craun, et el, 2006).

During the 1991 - 2002 time span, deaths from WBDO were caused by Salmonella typhimurium, Vibro cholerae, Legionella, E.coli 0157:H7, Camphlobactor jujuni, excess fluoride concentration, and norovirus (Craun et al. 2006). The potential for all of these WBDO can be and is reduced by an engineered water treatment process, which includes coagulation, filtration, and disinfection.

Disinfection, while reducing the number of WBDO, is not without possible danger. A concern from using disinfectants is that it will interact with the natural organic matter present in the water and cause the introduction of disinfection by-products (DBPs), these DBPs may cause cancer in humans are many are regulated by the United States Environmental Protection Agency. 


\section{Chapter 2 Literature Review}

Water treatment can be traced as far back as the early Egyptians where they reportedly treated their drinking water supply with a coagulant (alum) to control turbidity as early as 1500 BC (Excel Water Technologies, 2007).

The addition of a coagulant is used to destabilize the natural organic matter (NOM) suspended particles by reducing their surface charge and allowing the particles to come together and form flocs. The flocs can then be removed by sedimentation and/or filtration. By reducing the amount of NOM through the water treatment process, the amount of chlorine needed is reduced. Less NOM requires less chlorine and, thus, would have less of a disinfection by-product (DBP) formation potential (interaction with the remaining NOM and thereby reduce the amount of DBPs formed): (Water Research Foundation, 2004).

NOM in water may be present in particle or colloidal form, them particles are usually associated with a negative charge surrounding them. Water treatment plants, in an attempt to decrease the amount of NOM present, may introduce a coagulant to the source water to destabilize the particles allowing them to come together and form flocs. The flocs are then heavy enough to settle out of the water column during the settling phase of water treatment. Without a coagulant present, the two negative charges (on the particles in the water) are expected to repel each other and make flocs less likely to form, thereby allowing more NOM to remain in the source water, as it would take more energy to overcome the double layer. The double layer refers to two parallel layers of charge surrounding 
the object (Figure 2.1). The first layer, the surface charge (either positive or negative (at a distance, $\mathrm{d}$, of zero), comprises ions adsorbed directly onto the object due to a host of chemical interactions. The second layer is composed of ions attracted to the surface charge via the Coulomb force (at distance d2), electrically screening the first layer. This second layer is loosely associated with the object, because it is comprised of free ions, which move in the fluid under the influence of electric attraction and thermal motion rather than being firmly anchored. This second layer is called the diffuse layer (Valle-Delgado, 2013).

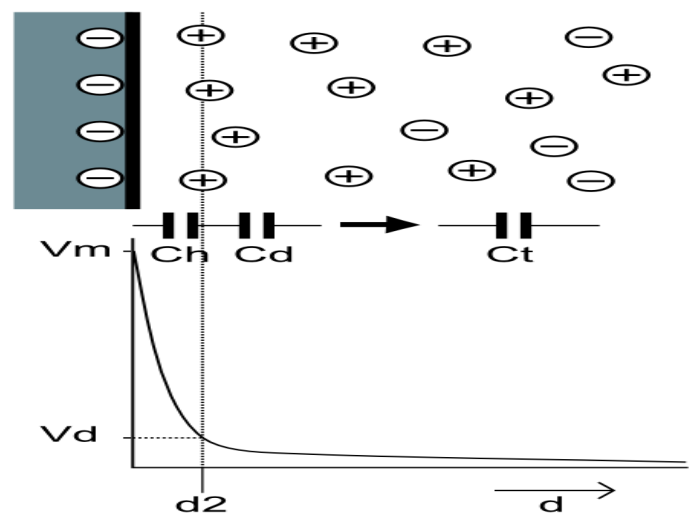

Figure 2.1 Electrical double layer of a negatively charged colloid (Tosaka 2008)

Filtration is another method of reducing the NOM present in source water. Membrane filtration (Figure 2.2) includes microfiltration, ultrafiltration, nanofiltration, and reverse osmosis. For microfiltration water is filtered through a membrane with a pore size between 0.1 and $10 \mu \mathrm{m}$. These membranes remove pathogens and particular NOM, e.g. yeast, pollens, red blood cells. However microfilters do not remove viruses, dissolved NOM, and other small organic and inorganic compounds, for this NOM filters would require a membrane with a pore size between 0.0001 and $0.1 \mu \mathrm{m}$ (Xie 2004). 


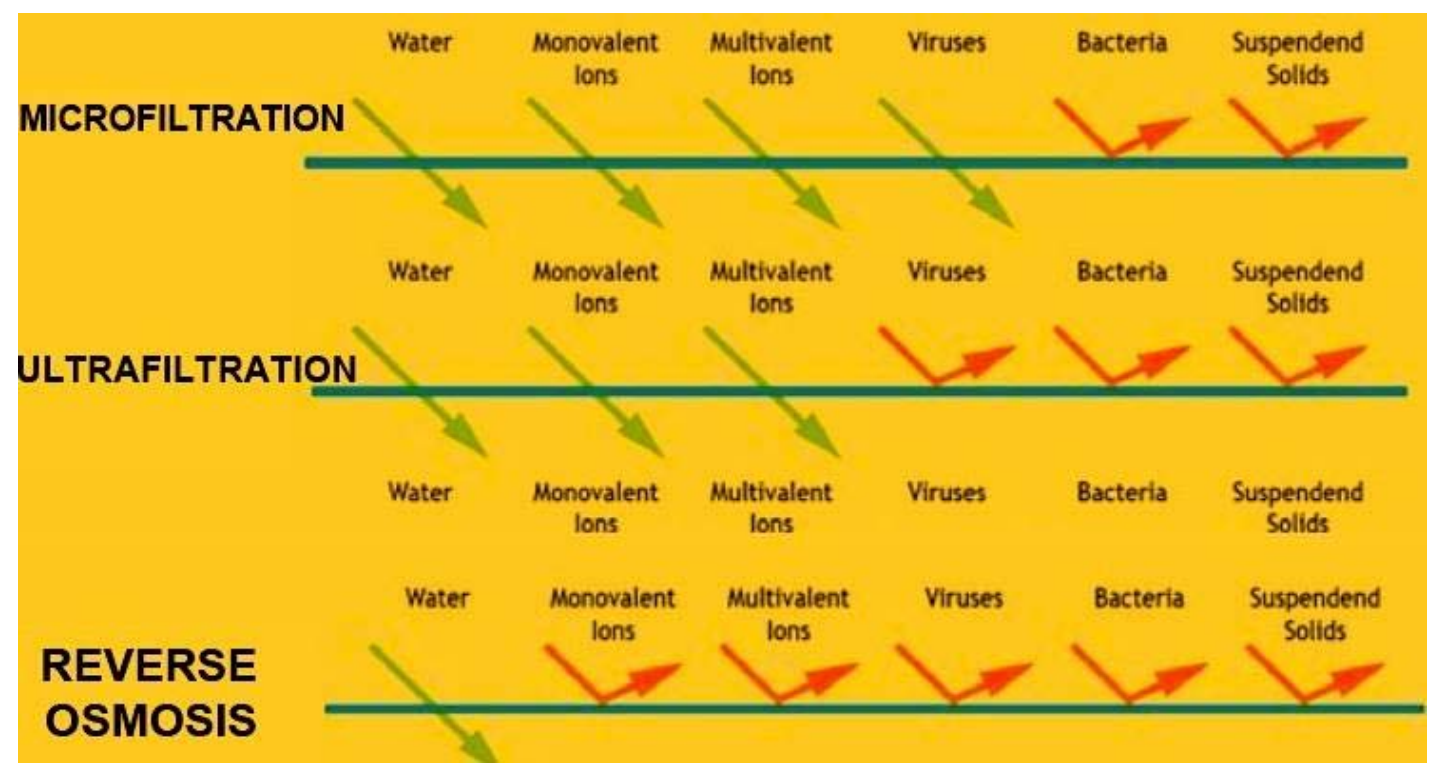

Figure 2.2 Overview of membrane separation by membrane type (UNSW3004SerG23 2013)

Ultrafiltration is a filtering process using pore sizes between 0.001 and 0.1

$\mu \mathrm{m}$. Typically, ultrafiltration will remove high molecular-weight substances, colloidal materials, and organic and inorganic polymeric molecules. Low molecular-weight organics and ions such as sodium, calcium, magnesium chloride, and sulfate are not removed.

Nanofiltration has been shown to be an excellent process for DBP precursor removal (Xie 2004) as the nominal pore size of the membrane is typically about $1 \mathrm{~nm}$ (or $0.001 \mu \mathrm{m}$ ). Because of the smaller pore size, nanofilters may be more subject to fouling (accumulation of materials on the membrane surface) and, therefore, anti-scaling products may be required.

Reverse osmosis removes $95-99 \%$ of most contaminants including microorganisms, organic compounds, dissolved inorganic compounds, microbial by-products such as endotoxins and pyrogens, and many carcinogenic 
compounds. Performance is given as percent rejection or the percentage of the contaminants removed from a given water supply.

Recent advances in technology have significantly reduced the cost of membrane-based systems. Installation costs are lower because membrane systems don't require large buildings or as much land as conventional systems. Operating costs are reduced because today's membranes produce more water and remove more impurities while using less energy (Koch Inc., 2013).

The disinfectant chlorine was first prepared by Scheele in 1774 but was not regarded as a chemical element until 1811 when Davy, after several experiments called it "chloros" from the Greek meaning pale green or yellow green (Chlorine, 2012). Chlorine was not used as a disinfectant until 1825 when it was used for wastewater treatment in France. Later, in 1831, chlorine was used as a prophylactic agent during the cholera epidemic in Europe (American Water Works Association, 1999). Continuous chlorination of drinking water in Great Britain in the early $20^{\text {th }}$ century sharply reduced typhoid deaths (Christman 1998). It was not until 1908 in Bubbly Creek (Chicago) that the Jersey City Water Company used chlorine as a disinfectant for drinking water. Within two years, chlorine was being utilized as a disinfectant in New York City, Montreal, Milwaukee, Cleveland, Cincinnati, Nashville, Baltimore, and other smaller treatment plants. Prior to the widespread use of chlorine to treat drinking water, typhoid fever killed approximately 25 out of 10,000 people in the United States annually (Christman 1998). In their 2004 article, "The Role of Public Health 
Improvements in Health Advances: The Twentieth Century United States," Cutler and Miller conclude that:

“...clean water technologies, filtration and chlorination, were responsible for nearly half of the total mortality reduction in major cities between 1900 and 1936, with even greater impact on infant and child mortality rates during that same time period. Significantly, these technologies led to the near-eradication of typhoid fever, the waterborne disease that was one of the major scourges of that era."

\subsection{CHLORINE / CHLORAMINES AS DISINFECTANTS}

Water disinfection is necessary to reduce the amount of pathogens, bacteria, and viruses being introduced into a distribution network, and, ultimately to consumers. Factors determining the level of disinfection based on regulations are the type of disinfectant used, the quality of the water being treated, and the presence of other environmental factors, such as any reducing compounds in the water, i.e. $\mathrm{H}_{2} \mathrm{~S}, \mathrm{Fe}^{2+}, \mathrm{Mn}^{2+}$, and $\mathrm{NO}_{2}^{-}$.

Chlorination remains the most common form of water disinfection in North America due to its low cost and long-term history of effectiveness. Water disinfection requirements can vary considerably due to season, organic compounds present, and ammonia concentrations.

Chlorine, and chlorine-based chemicals have been the disinfectant of choice for treating drinking water. Ninety-eight percent of systems that treat water use chlorine-based disinfectants (Christman 1998), and according to a 1995 survey, the USEPA stated approximately $64 \%$ of community ground water and surface water systems disinfect their water with chlorine (Excel Water Technologies, 2007). However, while the use of disinfectants has a direct benefit 
in reducing or even preventing WBDO, there may be a chronic health effect based on the DBPs formed when the chlorine disinfectant interacts with the NOM in the source water.

Chlorine is commonly added to water as chlorine gas or hypochlorite. Chlorine gas produces the following reaction when introduced into water:

$$
\mathrm{Cl}_{2}+\mathrm{H}_{2} \mathrm{O} \rightarrow \mathrm{HOCl}+\mathrm{HCL} \quad \text { (Eqn 1) }
$$

and as $\mathrm{pH}$ increases the hypochlorous acid converts to hydrogen ion and hypochlorite ion. One hundred percent of the hypochlorous acid is present up to $\mathrm{pH} 4$, then as the $\mathrm{pH}$ increases there is a transition to the hypochlorite ion until $\mathrm{pH}$ 10 where the hypochlorite ion is at $100 \%$ concentration.

Hypochlorite, or bleach, is sensitive to heat and light and may degrade before being able to interact with pathogens in the water. Hypochlorite react similar to chlorine gas, the following reaction of sodium hypochlorite with water is:

$$
\mathrm{NaOCl}+\mathrm{H}_{2} \mathrm{O}=\mathrm{HOCl}+\mathrm{NaOH} . \quad \text { (Eqn 2) }
$$

Regardless of the type of chlorine used, there needs to be a sufficient quantity to form a residual after killing or inactivating the microorganisms and other chlorine demanding substances in the water. Figure 2.3 depicts the process under which chlorine reaches the "break point chlorination" point and results in a free chlorine residual being present.

Prior to point 1 , the water reacts with reducing compounds in the water, such as hydrogen sulfide, to produce sulfide, water, and two chloride ions or sulfuric and hydrochloric acids 


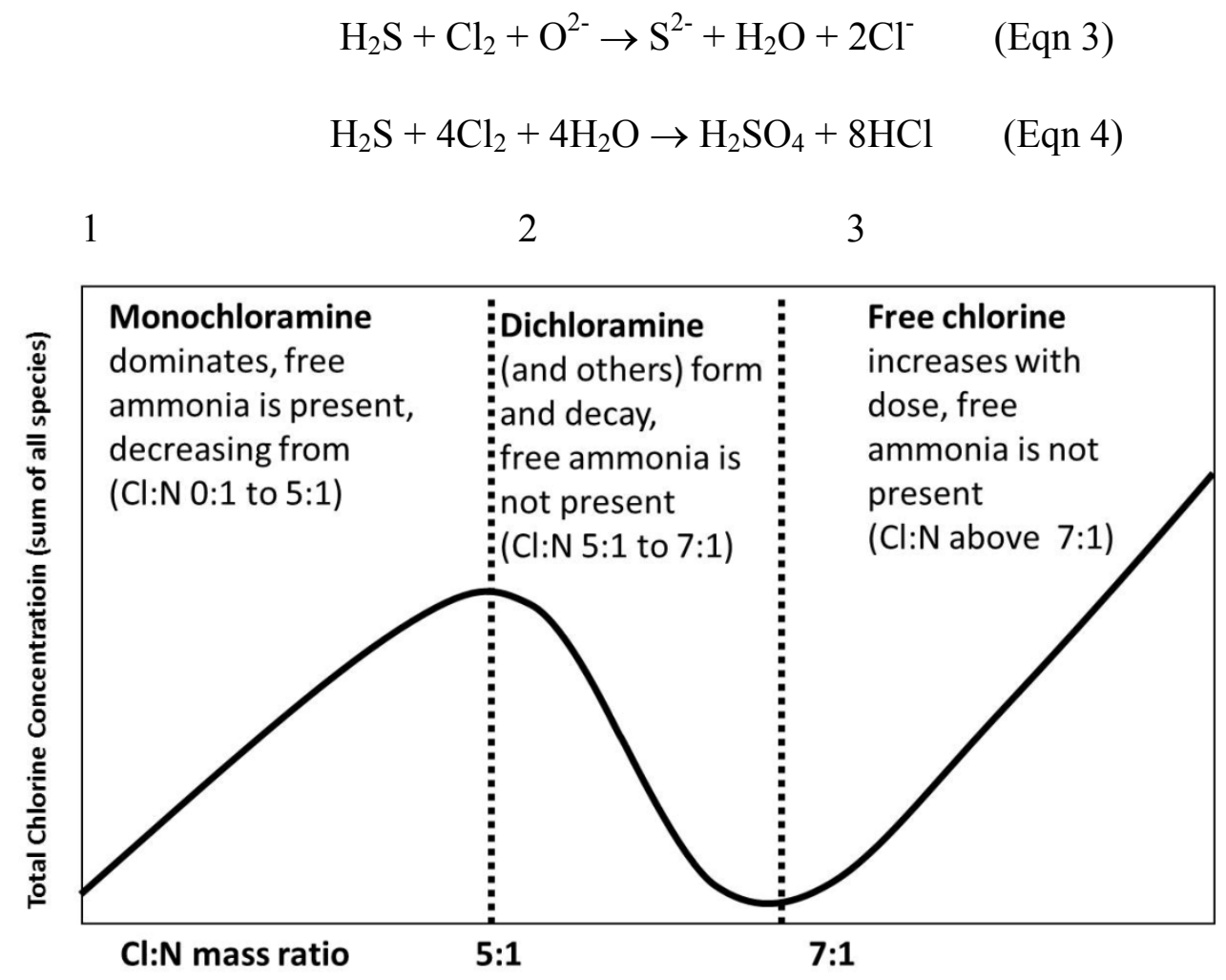

Figure 2.3 Breakpoint chlorination curve (Diehl 2012)

These compounds use up the chlorine, producing no chlorine residual.

Next, between points 1 and 2, the chlorine reacts with organics and ammonia naturally found in the water. Some combined chlorine residual, predominantly chloramines, is formed.

Using chloramine as the disinfecting agent results in little trihalomethane production but causes taste and odor problems because chloramines typically give a "swimming pool" odor to water (Wisconsin Department of Natural Resources, 2014).

Note that if chloramines are to be used as the disinfecting agent, more ammonia would be added to the water to react with the chlorine. The process would be stopped at point 2, where the predominant species is monochloramine 
(Equation 5).

$$
\mathrm{HOCl}+\mathrm{NH}_{3} \rightarrow \mathrm{NH}_{2} \mathrm{Cl} \text { (Monochloramine) }+\mathrm{H}_{2} \mathrm{O}
$$

In contrast, if hypochlorous acid continues to be used as the chlorine residual, chlorine will be added past point 2. Between points 2 and 3 , the chlorine will break down most of the chloramines in the water, actually lowering the chlorine residual.

Finally, the water reaches the breakpoint, shown at point 3 . The breakpoint is the point at which the chlorine demand has been totally satisfied; the chlorine has reacted with all reducing agents, organics, and ammonia in the water. When more chlorine is added past the breakpoint, the chlorine reacts with water and forms hypochlorous acid in direct proportion to the amount of chlorine added. This process, known as breakpoint chlorination, is the most common form of chlorination, in which enough chlorine is added to the water to bring it past the breakpoint and to create a free chlorine residual (Wisconsin Department of Natural Resources, 2014).

When chlorine is added to water containing ammonia $\left(\mathrm{NH}_{3}\right)$, chlorine will replace one hydrogen ion on the ammonia molecule with a chloride ion (Equation 5), resulting in the formation of monochloramine.

If the free chlorine-to-ammonia ratio is below 5:1 by weight (either by chlorine loss or by the addition of ammonia to the sample), all free chlorine will be converted to monochloramine. Between the $\mathrm{pH}$ range of $7-8$, this reaction takes place almost instantaneously. If the chlorine to ammonia ratio is above $5: 1$, the additional chlorine will displace a second hydrogen ion from the 
monochloramine molecule and replace it with another chloride ion (Equation 6), resulting in the formation of dichloramine.

$$
\mathrm{HOCl}+\mathrm{NH}_{2} \mathrm{Cl} \rightarrow \mathrm{NHCl}_{2} \text { (Dichloramine) }+\mathrm{H}_{2} \mathrm{O} \text { (Eqn 6) }
$$

The third member of the chloramines group, trichloramine, is similarly formed. Additional chlorine reacts with dichloramine to form the tri-substituted trichloramine (Equation 7; commonly referred to as nitrogen trichloride).

$$
\mathrm{HOCl}+\mathrm{NHCl}_{2} \rightarrow \mathrm{NCl}_{3} \text { (Trichloramine) }+\mathrm{H}_{2} \mathrm{O}(\text { Eqn 7) }
$$

At this point, if enough chlorine is added to bring the chlorine-to-ammonia ratio up to 10:1, the mono- and dichloramines are almost completely destroyed and converted back into less offensive nitrogen compounds and chloride salts as:

$$
2 \mathrm{NHCl}_{2}+2 \mathrm{HOCl} \rightarrow \mathrm{N}_{2}+6 \mathrm{Cl}-+2 \mathrm{H}_{2} \mathrm{O}(\text { Eqn } 8)
$$

This is similar to the "break-point" chlorination point depicted in Figure 1.4. Marahba and Washington (1998) suggest one disinfection by-product of chloramines is the formation of more haloacetic acids (HAAs). Nitrosamines are also a common disinfection by-product of chloramination. The presence of these nitrogen compounds in a drinking water distribution system may also cause nitrification in the system.

Although it has been reported that chlorine application is very effective against bacteria, it requires very high doses for cyst and virus inactivation, and Venczel et al. (1997) found free chlorine provided no measureable inactivation of Cryptosporidium parvum oocysts in 4 versus 24 hours (Lazarova et al. 1999). Another disadvantage is that chlorination of residual organic material (humic and 
fulvic acids) can generate chlorinated-organic compounds that may be carcinogenic or harmful to the consumer (Crebelli et al. 2005).

\subsection{DISINFECTION BY PRODUCTS}

The importance of the use of disinfectants cannot be stressed enough. Without their use, vast populations would be prone to numerous waterborne illnesses. However, it is the use of disinfectants that cause another problem: disinfection by products (DBPs). Chemical disinfectants can interact with the NOM to form many different types of DBPs, such as:

- trichloroacetaldehyde and its bromated analogues,

- haloacetonitriles,

- halopropanones,

- trichloronitromethane and its bromated analogues,

- cyanogen chloride and its bromated analogues,

- 3-chloro-4-(dichloromethyl)-5-hydroxy-2(5H)-furanone (MX), and

- (E)-2-chloro-3-(dichloromethly)-4-oxobutenoic acid (E-MX) an isomer of MX.

Other disinfection methods like ozone produce their own set of DBPs: aldrhydes, ketoacids, carboxylic acids, and $\mathrm{N}$-Nitrosodimethylamine (NDMA) (Xie 2004).

\subsubsection{Trihalomethanes}

Trihalomethanes (THMs), a class of organic compounds, are based on the methane molecule $\left(\mathrm{CH}_{4}\right)$ where the hydrogen atoms normally present are replaced by halogen atoms (chlorine, bromine, fluorine and/or iodine). The regulated 
THMs are made up of chlorine and bromine atoms (Figure 2.4).

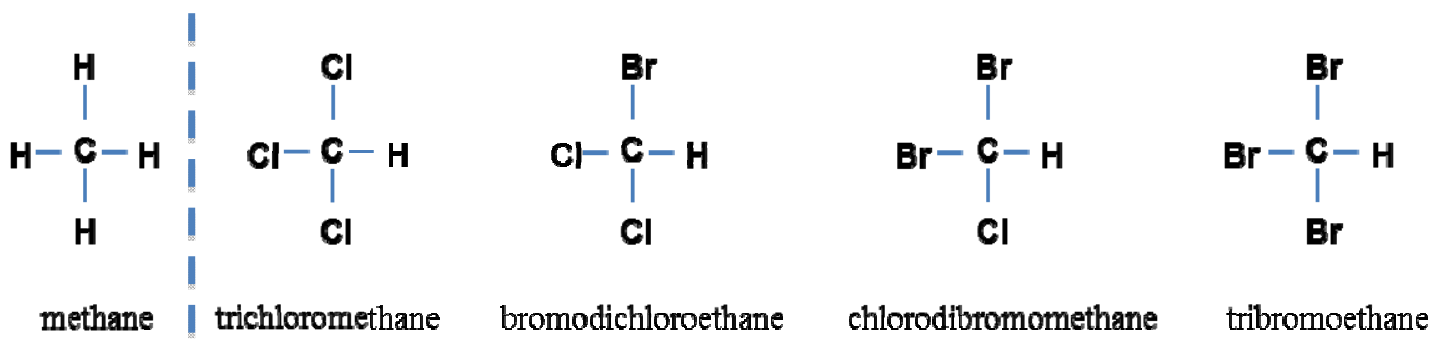

Figure 2.4 Molecular structures of methane and four regulated THMs. (Modified from Disinfection By-Products in Drinking Water, Formation, Analysis, and Control, Xie 2004)

\subsubsection{Haloacetic Acids}

Haloacetic acids (HAAs) are carboxylic acids, a family of organic compounds based on the acetic acid molecule $\left(\mathrm{CH}_{3} \mathrm{COOH}\right)$ in which a halogen atom (chlorine, bromine, fluorine and/or iodine) takes the place of a hydrogen atom in acetic acid. Of these halogens, only the chlorinated species are shown. Additionally, of the nine HAAs, only five are currently regulated and are shown along with acetic acid; Monochloroacetic acid (MCAA), Dichloroacetic Acid (DCAA), Trichloroacetic Acid (TCAA), Monobromoacetic Acid (MBAA), and Dibromoacetic Acid (DBAA) (Figure 2.5).

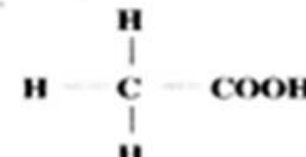

axctic anid<smiles>O=C(O)C(Cl)Cl</smiles>

dichloroacetic acid<smiles>O=C(O)CCl</smiles>

monochloroacetic acid<smiles>O=C(O)C(Cl)(Cl)Cl</smiles>

Iinhloroscetic acid<smiles>O=C(O)CBr</smiles>

monobromoacetic acid<smiles>O=C(O)C(Br)Br</smiles>

dibromoacetic acid 
Figure 2.5 Molecular structures - acetic acid and the five regulated haloacetic acids (Modified from Disinfection Byproducts in Drinking Water, Formation, Analysis, and Control, Xie 2004)

\subsection{TREATMENT/CONTROL PROCESSES}

The type of treatment process chosen to control DBPs is not a "one size fits all" solution. Many factors need to be considered when choosing a treatment strategy; the quality of the source water, NOM, contaminants present, costs, chlorine residual, reaction time, $\mathrm{pH}$ and pathogens present. Regardless of the process chosen, the treatment still must meet the regulatory requirements. The maximum contaminant level (MCL) for $\mathrm{HAA}_{5}$ is $0.06 \mathrm{mg} / \mathrm{L}$ and for TTHMs is $0.080 \mathrm{mg} / \mathrm{L}$ (USEPA, 2013).

Figure 2.6 illustrates a typical water treatment plant (WTP). As the source water enters the WTP, it passes through a screen to remove trash and other debris. A pre-oxidant may then be added before the chemical coagulant. The water will enter a rapid mix basin to thoroughly mix the coagulant throughout the water and then will flow into a coagulation basin where the NOM will be gently mixed to encourage flocculation. Subsequently the water will enter into the clarifier where the flocs will be allowed to settle out of the water column through gravity and removed to the solids lagoon. The water will then flow through a filter system to further remove NOM. It is after filtration when the disinfectant is added. This process reduces the amount of time the disinfectant has to react with the NOM present as well as reducing the amount of NOM remaining. Finally the water is sent out through the distribution system to the consumer. 


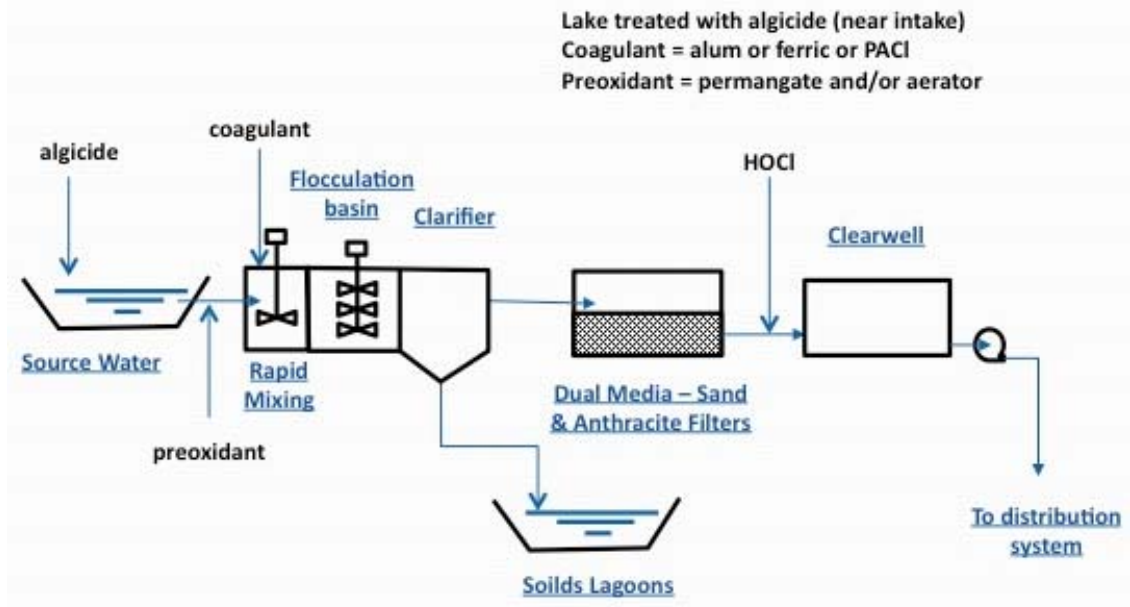

Figure 2.6 depicts a typical water treatment plant indicating chemical addition points throughout the treatment process.

\subsubsection{PRE-OXIDATION}

Oxidants applied toward the start of a drinking water treatment process are traditionally used to control taste, odor, color, iron, and manganese. It may also aid in the reduction of DBPs. By making NOM reaction sites inactive to further chlorination (Xie 2004), the chlorine demand is reduced. Regulated DBP reduction through pre-oxidation is dependent upon water quality parameters and characteristics of the NOM present.

\subsubsection{CARBON ADSORPTION}

Granulated activated carbon (GAC) and powdered activated carbon (PAC) have been used for the elimination of taste, odor, pesticides, herbicides, and other natural and synthetic organic compounds.

The use of carbon has been primarily used in the removal of DBP precursors. If used early in the process, the removal of precursors reduces the amount of NOM available to interact with the added chlorine, reducing the amount of DBPs formed. 
The USEPA lists GAC, with an empty bed contact time of 10 minutes and reactivation frequency of no more than six months, as a best available technology (BAT) for DBP control (USEPA, 1992).

\subsubsection{BIO-FILTRATION (i.e. Biologically Active Filtration)}

Bio-filtration relies on microorganisms to aid in the treatment of drinking water. Biological treatment can help remove contaminants, taste and odor compounds, pharmaceuticals, iron, manganese, ammonia, nitrate and perchlorate (Evans 2010, Xie 2004). In addition to the proven capabilities of current filtration systems (i.e. slow sand, rapid-rate, and GAC), the addition of a biological component can further aid in the delivery of high quality water. The microorganisms may aid in DBP removal. In a 2008 study it was found HAAs were biodegraded under aerobic conditions (Hozalski et al, 2008). Similarly in 2010 using plug flow reactors, it was demonstrated that HAA removal through bacterial activity is possible within bio-filters as well as along pipe walls in the distribution system (Grigorescu and Hozalski, 2010).

The biological component becomes less dominant in a rapid-rate filtration system. The rapid-rate system utilizes dual media, such as sand and anthracite, coagulants, and perhaps a pre-oxidant. If the effluent placed on a filter does not contain a pre-oxidant residual, then the filter is considered biologically active (Evans 2010). The large surface area of granulated activated carbon (GAC) allows the accumulation of a large amount of biomass to form; the bio-film adsorbed to the GAC can increase the useful life of the product as the biomass aids in contaminant removal. 


\subsubsection{ENHANCED COAGULATION}

Under the USEPA Disinfectants and Disinfection Byproducts (D-DBP) Rule, a coagulation process optimized for a specific NOM removal (in additional to the primary purpose of turbidity removal) has been defined as enhanced coagulation (USEPA 2014). Under the Stage 1 requirements, a certain percentage of NOM removal in conventional treatment systems is required (USEPA 2014). Enhanced coagulation is defined as an optimal coagulation process for removing DBP precursors, or NOM. In general, enhanced coagulation is practiced at a higher coagulant dose and a lower pH, usually between 5 and 6 (AWWA 1999, Xie 2004).

\subsubsection{CHLORINATION POINT}

Similar to the measure of effectiveness of the disinfectant for the inactivation of pathogens in water treatment, disinfection by-products formation results from a combination of chlorine dose and contact time. DBP formation is most rapid during the first 24 hours; nearly $42 \%$ of the total DBPs formed are generated during the first 24 hours (Figure 2.7). 


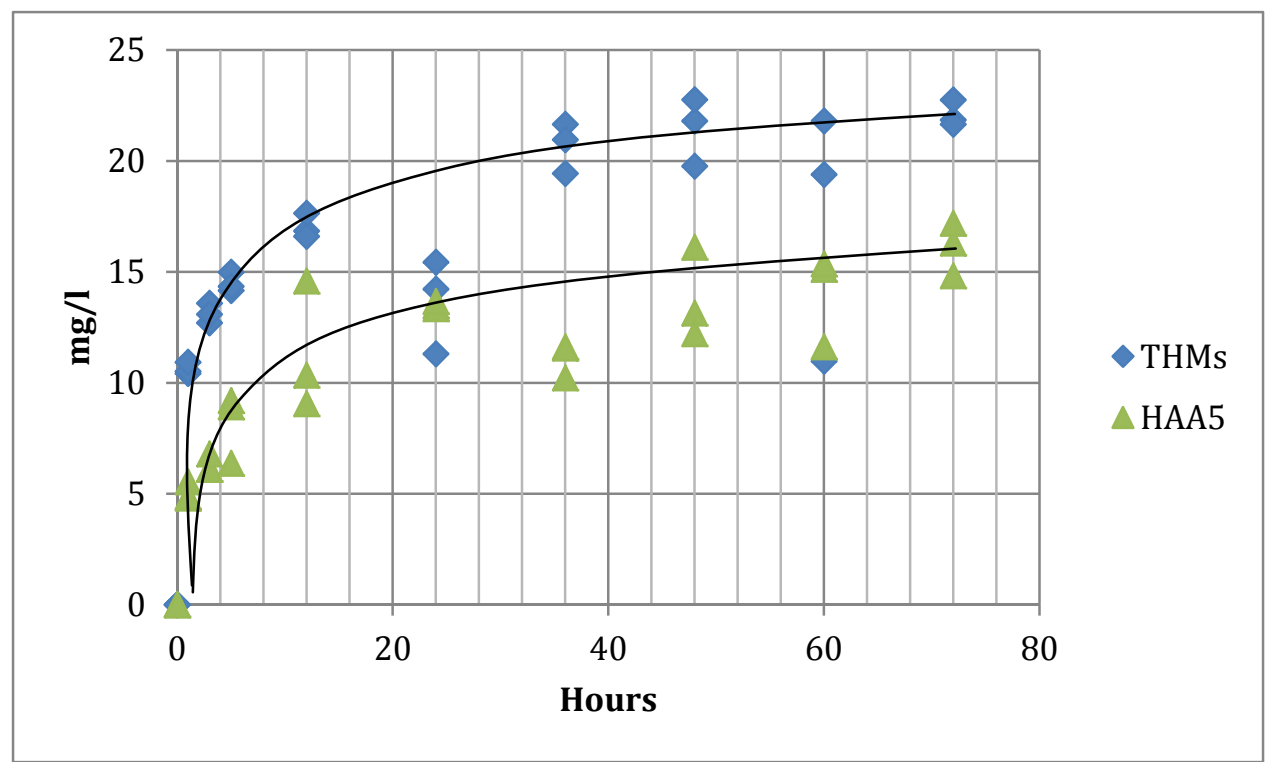

Figure 2.7 Rate of DBP Formation based on contact time

Water treatment facility operators may add chlorine early in the treatment process and as a result of the kinetics shown above may experience a large number of DBPs before the water leaves the treatment facility. One possible method to reduce the number of DBPs formed would be to move the point of chlorination to later in the treatment process, perhaps after coagulation/flocculation and sedimentation. If the chlorine disinfectant were to be added at this point there would be less NOM for the chlorine to react with, thereby decreasing the necessary chlorine dose to achieve the level of disinfection needed. Additionally, there would be less opportunity for DBP formation, as the contact time would be decreased as well. The actual placement of the chlorine addition would depend on the contact time required to achieve the proper level of disinfection to meet the USEPA requirement for drinking water. (USEPA 1999). 


\subsection{6 pH ADJUSTMENT}

The quantity of DBPs formed during chlorination may be dependent upon the $\mathrm{pH}$ level of the treatment water (AWWA 1999; Xie 2004), Kim et al (2002) found when $\mathrm{pH}$ increased the THMfp (formation potential) increased and as $\mathrm{pH}$ decreased the HAAfp increased. These two different trends indicate a tradeoff between these two categories of regulated DBPs based upon the operating $\mathrm{pH}$ range of the water treatment plant. Figure 2.8 depicts the theoretical representation of the DBP concentration based on $\mathrm{pH}$.

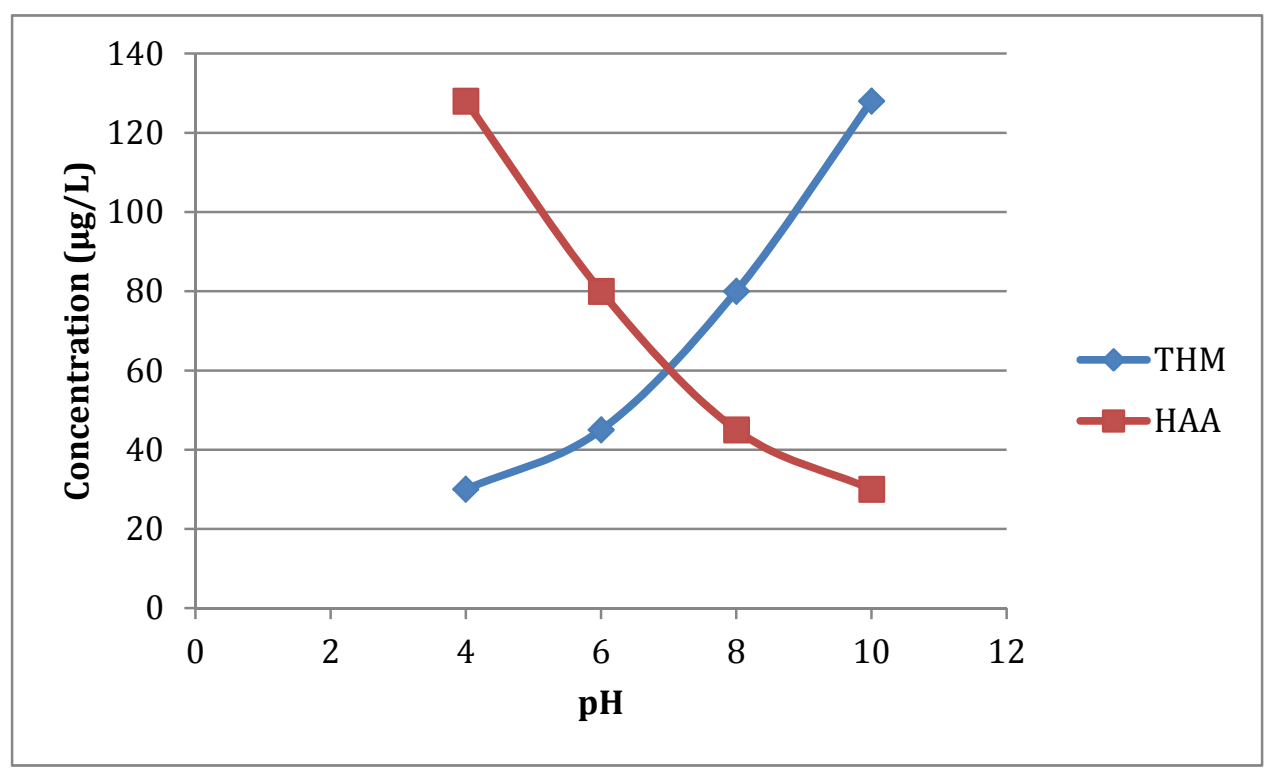

Figure 2.8 Theoretical Variations of DBPFP with $\mathrm{pH}$

The decrease in HAAs, made up of predominantly hydrophobic fractions, i.e., proteins, may be explained by the way $\mathrm{pH}$ affects proteins. The level of $\mathrm{pH}$ can cause the proteins to unfold, which will stay folded as long as it remains within its isoelectric zone, between $\mathrm{pH} 4$ and 7 (Halsey, C., personal communication, April 13, 2011). The isoelectric point is the $\mathrm{pH}$ at which a 
particular molecule or surface carries no net electrical charge. Proteins are naturally in a globular formation and if the environmental $\mathrm{pH}$ is outside of their isoelectric range in either direction, then the protein will begin to unfold causing the protein hydrophobic beta layer to be exposed (Dr. Emerich University of Missouri Biochemistry Department, 2014). With an increase in $\mathrm{pH}$ above the protein isoelectric point, the unfolding allows more hydrophobic base surfaces to come into contact with the disinfectant, which, also at the elevated $\mathrm{pH}$ is mainly negatively charged hypochlorite ions $\left(\mathrm{OCl}^{-}\right)$.

The level of $\mathrm{pH}$ also seems to affect the species of HAA formation as well. When $\mathrm{pH}$ is acidic $(<7)$, trichloroacetic acid is form more readily than at higher $\mathrm{pH}$ levels. However, at basic $\mathrm{pH}$, mono- and dichloroacetic acid formation is greater (Kim et al. 2002; Nikioaou et al. 2004).

\section{$2.4 \quad$ Fractionation}

Fractionation is the separation of water into its six different organic components based on its behavior; hydrophobic acids, bases, and neutral and hydrophilic acids, bases and neutrals. The procedure developed by Leenheer (1981) is among the most widely adopted. This method was modified later by Marhaba and $\mathrm{Pu}$ (2000), and again by Marhaba et al. (2003), who proposed new methods that are capable of identifying six dissolved organic fractions in low organic matter sources (Kanokkantapong et al. 2005).

Generally speaking, fractionation is usually achieved by running the source water through a column containing a resin so that each water fraction will adsorb with the column effluent collected. This effluent is adjusted and then 
poured through a different column containing another resin for the next component to be adsorbed. The process is repeated until all water fractions have been isolated onto a resin or left in the final effluent. To remove the individual fractions that have adsorbed onto the resins, the column is back-washed with an acid, base, or alcohol (Kanokkantapong et al. 2005).

More explicitly, NOM in source water can be separated into six fractions: hydrophobic acids (HPOA), hydrophobic bases (HPOB), hydrophobic neutrals (HPON), hydrophilic acids (HPIA), hydrophilic bases (HPIB), and hydrophilic neutrals (HPIN). Some fractions minimally contribute to DBPs (HPIA, HPON). One may be easily removed through the use of coagulants (HPOA), and the remainder (HPOB, HPIB, HPIN) may be considered to be the main contributors to DBPFP based on current treatment process sequences (Kanokkantapong et al. 2005).

\subsection{Environmental Factors of Source Water of DBP Formation}

Natural organic matter (NOM) is thought to be reactive with disinfectants and thus can lead to the formation of DBPs (Kanokkantapong et al. 2005). NOM is made up of fulvic acids, (one of two classes of natural acidic organic polymer that can be extracted from humus found in soil, sediment, or aquatic environments), and humic acids. Fulvic acid is organic matter that is soluble in strong acid $(\mathrm{pH}=1)$ and has the average chemical formula $\mathrm{C}_{135} \mathrm{H}_{182} \mathrm{O}_{95} \mathrm{~N}_{5} \mathrm{~S}_{2}$. A hydrogen-to-carbon ratio greater than 1:1 indicates less aromatic character (i.e., fewer benzene rings in the structure), while an oxygen-to-carbon ratio greater than 0.5:1 indicates a more acidic character than in other organic fraction of humus. Its 
structure is best characterized as a loose assembly of aromatic organic polymers with many carboxyl groups $(\mathrm{COOH})$ that release hydrogen ions, resulting in species that have electric charges at various sites on the ion. It is especially reactive with metals, forming strong complexes with $\mathrm{Fe}^{3+}, \mathrm{Al}^{3+}$, and $\mathrm{Cu}^{2+}$ in particular and leading to their increased solubility in natural waters. Fulvic acid is believed to originate as a product of microbial metabolism, although it is not synthesized as a life-sustaining carbon or energy source (Stevens 1994; Encyclopedia Britannica, 2011).

Humic acid has the average chemical formula $\mathrm{C}_{187} \mathrm{H}_{186} \mathrm{O}_{89} \mathrm{~N}_{9} \mathrm{~S}_{1}$ and is insoluble in a strong acid $(\mathrm{pH}=1)$. A 1:1 hydrogen-to-carbon ratio indicates a significant degree of aromatic character (i.e., the presence of benzene rings in the structure), whereas a low oxygen-to-carbon ratio indicates fewer acidic functional groups than occur in fulvic acid. Transition and heavy metals—-for example, $\mathrm{Fe}^{3+}$ or $\mathrm{Pb}^{2+}$-as well as other compounds having aromatic or hydrophobic (waterinsoluble) chemical structures (i.e., organic pesticides or anthropogenic hydrocarbons), react strongly with humic acid (Encyclopedia Britannica, 2011). This means that the conventional treatment process which adds metal coagulants is more effective at reducing humic acids than fulvic acids.

In addition to NOM in the source water, naturally occurring alkalinity from carbonate rocks and the presence of carbon dioxide in the atmosphere can affect the potential formation of DBPs by varying the amount of base ions as well as the $\mathrm{pH}$ of the source water. 


\subsubsection{Commonly Found Compounds as NOM}

The following list details (Kanokkantapong et al. 2005) the types of NOM of which each fraction is comprised:

1. Hydrophobic acids (HPOA) aliphatic carboxylic acids of five to nine carbons, one-and two-ring aromatic carboxylic acids, aromatic acids, one and two-ring phenols, and tannins.

2. Hydrophobic bases (HPOB) proteins, one and two-ring aromatic amines except for pyridine, and high molecular weight alkyl.

3. Hydrophobic neutrals (HPON) hydrocarbon; aliphatic alcohols, alkyl alcohols, ethers, ketones, and aldehydes, aliphatic carboxylic acids and aliphatic amines with more than five carbons, aromatic carboxylic acids with more than nine carbons and aromatic amines of three rings and greater.

4. Hydrophilic acids (HPIA) aliphatic acids of less than five carbons, hydroxyl acids, sugars, low molecular weight alkyl monocarboxylic and dicarboxylic acids.

5. Hydrophilic bases (HPIB) aliphatic amines with less than nine carbons, amino acids, pyridines, purines, pyrimidines, and low molecular weight alkyl amines.

6. Hydrophilic neutrals (HPIN) aliphatic amides, alcohols, aldehydes, esters, ketones with less than five carbons, and polysaccharides.

\subsubsection{Alkalinity}

Alkalinity is a measure of the ability of a solution to neutralize acids to the equivalence point of carbonate or bicarbonate. The alkalinity is equal to the stoichiometric sum of the bases in solution; $\mathrm{HCO}_{3}{ }^{-}, \mathrm{CO}_{3}{ }^{2-}$, and $\mathrm{OH}^{-}$. The amount of each is dependent on the $\mathrm{pH}$ range of the water; with lower $\mathrm{pH}$ favoring $\mathrm{HCO}_{3}^{-}$, and a higher $\mathrm{pH}$ favoring a transition from $\mathrm{HCO}_{3}{ }^{-}$to $\mathrm{CO}_{3}{ }^{2-}$ to $\mathrm{OH}^{-}$(Figure 2.9). 


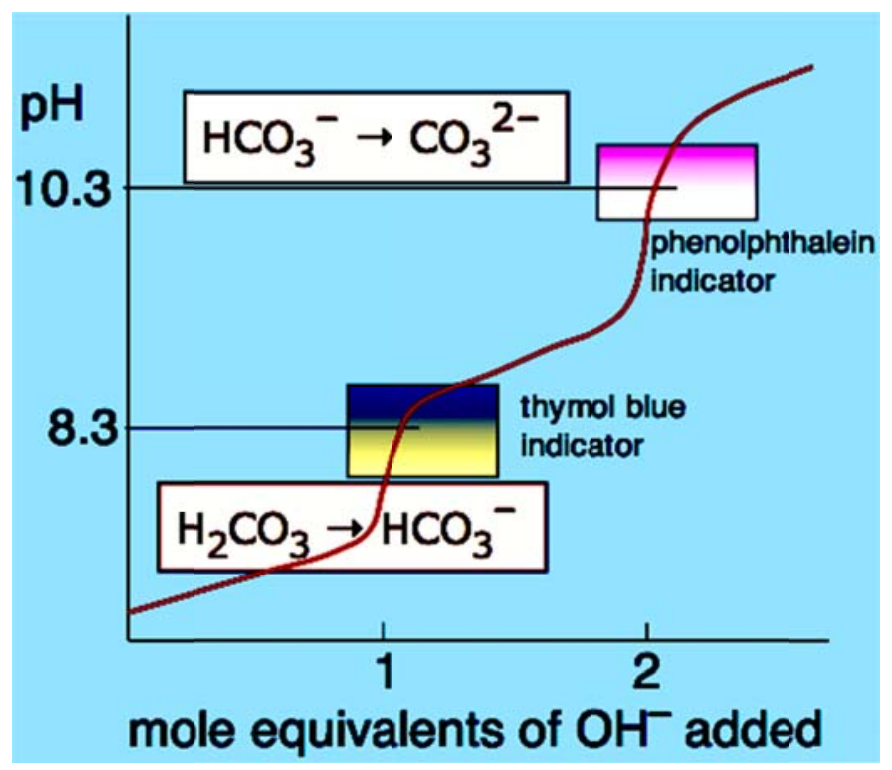

Figure 2.9. Base species based upon pH (Slower 2006)

In the natural environment, carbonate alkalinity tends to make up most of the total alkalinity due to the common occurrence and dissolution of carbonate rocks and the presence of carbon dioxide in the atmosphere. Other common natural components that can contribute to alkalinity include borate, hydroxide, phosphate, silicate, nitrate, dissolved ammonia, the conjugate bases of some organic acids and sulfide. (Pradeep et al., 2014)

\subsubsection{Hardness}

Hard water is water that has a high concentration of divalent cations, i.e., a charge greater than $1^{+}$, consisting predominantly $\mathrm{Ca}^{2+}$, and $\mathrm{Mg}^{2+}$. These ions enter a water supply by leaching from minerals within an aquifer where common calcium-containing minerals such as calcite and gypsum are found. The common magnesium mineral dolomite also contains calcium.

Because it is the precise mixture of minerals dissolved in the water, together with the water's $\mathrm{pH}$ and temperature, that determines the behavior of the 
hardness, a single-number scale does not adequately describe hardness. Descriptions of hardness correspond roughly with ranges of mineral concentrations (Table 2.1) with the preferred range being based upon individual preferences.

Table 2.1 Water Hardness Levels Concentrations in $\mathrm{mg} / \mathrm{L}$ as $\mathrm{CaCO}_{3}$ (modified from United States Geographical Survey 2013)

\begin{tabular}{|c|c|}
\hline Soft: & $0-60 \mathrm{mg} / \mathrm{L}$ \\
\hline Moderately hard: & $61-120 \mathrm{mg} / \mathrm{L}$ \\
\hline Hard: & $121-180 \mathrm{mg} / \mathrm{L}$ \\
\hline Very hard: & $>181 \mathrm{mg} / \mathrm{L}$ \\
\hline
\end{tabular}

\subsection{4 pH}

In chemistry, $\mathrm{pH}$ is a measure of the acidity $\left(\mathrm{H}^{+}\right.$ions $)$or basicity $\left(\mathrm{OH}^{-}\right.$ ions) of an aqueous solution. The $\mathrm{pH}$ is calculated from the following equation.

$$
\mathrm{pH}=-\log \left[\mathrm{H}^{+}\right](\text {Eqn 12) }
$$

Pure water is said to be neutral, with a $\mathrm{pH}$ close to 7.0 at $25^{\circ} \mathrm{C}\left(77^{\circ} \mathrm{F}\right)$. Solutions with a $\mathrm{pH}$ less than 7 are said to be acidic and solutions with a $\mathrm{pH}$ greater than 7 are basic or alkaline. The $\mathrm{pH}$ value in source waters is primarily due to the soil types the water comes in contact with: soils with high carbonate materials, such as limestone, will have a higher $\mathrm{pH}$ than waters that come in contact with granite. Human effects can also affect the $\mathrm{pH}$ in source water such as manmade atmospheric pollutants causing acid rain. When water enters a treatment plant, the $\mathrm{pH}$ may need to be taken into account to provide for the best treatment strategy. 


\subsection{Other Studies}

Previous experiments have been conducted to evaluate how environmental factors contribute to DBPfp, NOM make-up, total organic carbon (TOC), dissolved organic carbon (DOC), UV-254, specific UV absorbance (SUVA), and turbidity have all been used as a surrogate to estimate the formation potential of DBPs.

Aromatic hydrocarbons in humic substances within DOC have been used to estimate the amount of THM formed (Rook 1977), and absorbance of ultra violet light at the wavelength of $254 \mathrm{~nm}$ has been to estimate the amount of aromatic organic carbon as well (Traina 1990). SUVA is defined as the UV absorbance divided by the DOC concentrations giving units of $\mathrm{L} / \mathrm{mg} / \mathrm{cm}$. The SUVA value, which includes both the UV-254 and the DOC measurements, has also been used as a predictor of THMfp. When SUVA was used to predict the THMfp for waters from the Sacramento and San Juan Rivers, it was found there was a meaningful linear relationship; however, SUVA did not provide linear relationships between other waters under test conditions (Fram et al, 1999).

\subsection{Scope of Work}

Water treatment entities may discount various treatment strategies because the treatment was performed at a separate location i.e., they reject the strategy by claiming "that process may work for your water but not ours". The study reported here examined how the environmental factors of hardness and alkalinity contribute to DBPfp. Starting with a set amount of alkalinity or hardness in the source water the "treatment" involved adjusting $\mathrm{pH}$ to the desired level in an 
attempt to determine the influence of common source water characteristics on the formation of DBPs.

These tests will show:

1: High alkalinity waters reduce the total trihalomethanes formed

2: High Hardness waters reduce the total trihalomethanes formed at high $\mathrm{pH}(\mathrm{pH} 10)$, and

3: Global Mean Value waters will provide optimal water conditions for reducing the total trihalomethanes formed. 


\section{Chapter 3 Methodology and Experimental Design}

\subsection{Typical Water Quality Estimation}

Source water exhibits various properties throughout the globe. Alkalinity, $\mathrm{pH}$, and hardness are each a property of location and therefore a solution to combat DBPs in one location may not necessarily work in another. However, for the purposes of these experiments an average water quality was utilized so that the DBP analysis results may be transferrable to a wider set of local sources than using a water source from one specific area.

The global mean alkalinity was calculated by averaging the 2000-2008 $\mathrm{CaCO}_{3}$ concentrations detailed by the United Nations Environment Programme; Australia was excluded from the mean because the continent has a $\mathrm{CaCO}_{3}$ value of $40 \mathrm{mg} / \mathrm{L}$, and thus would require an adjustment to a higher alkalinity to be considered stable. South America was also excluded because the alkalinity value is approximately $50 \%$ of that of the rest of the world.

The weighted global mean value of water hardness is calculated by taking the average values found in the second edition of Water Quality for Ecosystems and Human Health. The water hardness locations were grouped to match the alkalinity locations by continent.

Synthetic water representative of the global water properties (Table 3.1) with the global mean average calculated in the last column, is prepared using deionized water passed through a Millipore UF with $\mathrm{CaCl}_{2}$ and $\mathrm{NaHCO}_{3}$ added to bring the water to the desired alkalinity and hardness. Proteins, a hydrophobic 
base fraction of a water (see section 2.4) were added to provide a known amount of NOM; the NOM amount being calculated from central Missouri water treatment plant TOC/DOC analysis. The sample water $\mathrm{pH}$ was adjusted to 7.5 (typical source water $\mathrm{pH}), 8.75$, and 10.0 using either $\mathrm{H}_{2} \mathrm{SO}_{4}(0.02 \mathrm{M})$ or $\mathrm{NaOH}$ $(0.1 \mathrm{M})$ depending upon the synthetic water $\mathrm{pH}$ after chemical addition.

Table 3.1. Global water parameters used for synthetic water determination

\begin{tabular}{|c|c|c|c|c|c|c|c|}
\hline $\begin{array}{c}\text { Parameter } \\
\text { (in mg/L } \\
\text { as } \\
\text { CaCO3) }\end{array}$ & $\begin{array}{c}\text { North } \\
\text { America, } \\
\text { Alaska, } \\
\text { Central } \\
\text { America, } \\
\text { Cuba, Mexico, } \\
\text { Canada) }\end{array}$ & $\begin{array}{c}\text { South } \\
\text { America }\end{array}$ & Europe & $\begin{array}{c}\text { Asia, } \\
\text { Russia, } \\
\text { India } \\
\text { Far - } \\
\text { East }\end{array}$ & Australia & Africa & Mean \\
\hline Alkalinity & 178 & Not Used & 150 & 158 & Not Used & 149 & $\mathbf{1 5 5 . 5}$ \\
\hline Hardness & 303.47 & 64.58 & 122.90 & 376.47 & 38.16 & 96.41 & $\mathbf{1 0 0 . 2}$ \\
\hline
\end{tabular}

\subsection{Variable Water Quality Experimental Plan}

Experiments were conducted to determine what, if any, contributions were made by environmental factors. If alkalinity is increased there should be a decrease in DBPfp, if hardness is increased at $\mathrm{pH} 10$ there will be a decrease in DBPfp, and the Global Mean Value of water will provide the optimal conditions for reducing the total trihalomethane formed.

Each set of experiments had six replicates and was conducted at four different $\mathrm{pH}$ settings to determine if DBP formation is impacted by water parameter (alkalinity and hardness) or $\mathrm{pH}$ (Table 3.2). The first set (jars 0 through 3) examined the effect of $\mathrm{pH}$ in moderate alkalinity water. The second set (jars 4-7) examined high alkalinity, and third set (jars 8-11) considered high alkalinity water as a function of $\mathrm{pH}$ with no influence from hardness. Sets four and five (jars 12-15 and 16-19) varied the hardness as a function of $\mathrm{pH}$ with no 
influence from alkalinity. When alkalinity is increased there should be a decrease in DBPfp, an increase in hardness at $\mathrm{pH} 10$ will result in a decrease in DBPfp as compared to low hardness, and the Global Mean Value of water will provide the optimal conditions for reducing the total trihalomethane formed.

Table 3.2 Experiment water parameters

\begin{tabular}{|c|c|c|c|}
\hline Jar Number & $\begin{array}{c}\text { Hardness } \\
(\mathrm{mg} / \mathrm{L} \text { as CaCO3) }\end{array}$ & $\begin{array}{c}\text { Alkalinity } \\
\text { (mg/L as CaCO3) }\end{array}$ & pH \\
\hline 0 & 0 & 100 & No $\mathrm{pH}$ adjustment \\
\hline 1 & 0 & 100 & 7.5 \\
\hline 2 & 0 & 100 & 8.75 \\
\hline 3 & 0 & 100 & 10.0 \\
\hline 4 & 0 & 155 & No $\mathrm{pH}$ adjustment \\
\hline 5 & 0 & 155 & 7.5 \\
\hline 6 & 0 & 155 & 8.75 \\
\hline 7 & 0 & 155 & 10 \\
\hline 8 & 100 & 0 & No $\mathrm{pH}$ adjustment \\
\hline 9 & 100 & 0 & 7.5 \\
\hline 10 & 100 & 0 & 8.75 \\
\hline 11 & 100 & 0 & 10.0 \\
\hline 12 & 160 & 0 & No $\mathrm{pH}$ adjustment \\
\hline 13 & 160 & 0 & 7.5 \\
\hline 14 & 160 & 0 & 8.75 \\
\hline 15 & 160 & 0 & 10 \\
\hline 16 & 100 & 155 & No $\mathrm{pH}$ adjustment \\
\hline 17 & 100 & 155 & 7.5 \\
\hline 18 & 100 & 155 & 8.75 \\
\hline 19 & 100 & 155 & 10 \\
\hline
\end{tabular}

To simulate a typical water treatment process (specifically the coagulation-flocculation-sedimentation sequence), the dosed water samples were rapid mixed at 100 revolutions per minute (rpm) for 30 seconds (to simulate coagulation), then slow mixed at $30 \mathrm{rpm}$ for 30 minutes (to simulate flocculation) followed by a 30 minute settling time (sedimentation). The mixing was conducted using a Phipps \& Bird Jar Tester. 
Settled turbidity, TOC, and UV-254 were tested prior to the water being filtered through a wetted $0.45 \mu \mathrm{m}$ mixed cellulose ester filter. DOC is measured after filtration.

The sample waters were then transferred to $125 \mathrm{ml}$ amber jars and chlorine dosed in accordance with the chlorine demand as determined by UFC test. The amber bottles were placed in the dark for 24, 48 and 72 hours. At the end of the reaction period, the samples were quenched with $\mathrm{NH}_{4} \mathrm{Cl}$ and samples were collected for DBP analysis. The 0 hour sample was quenched immediately after chlorine addition to stop the chlorine/NOM reaction. After quenching, the samples were placed in a dark refrigerated environment until analyzed.

\subsection{Making Synthetic Water}

One liter of de-ionized water (Culligan, Columbia MO) was ultra-filtered (resistivity > $18 \mathrm{M} \Omega$ ) using a Millipore Simplicity 185 unit (Millipore, St.

Charles, $\mathrm{MO}$ ). To achieve an alkalinity of $155+/-5 \mathrm{mg} / \mathrm{l}$ as $\mathrm{CaCO}_{3}$, as tested by using Hach Method 8221, $0.3000+/-0.0005 \mathrm{mg} \mathrm{NaHCO}$ (Fisher Scientific) was added to the ultra-filtered water. The desired water hardness of $100+/-5$, as tested by using Hach Method 8226, was achieved by adding $0.1250+/-0.0005$ $\mathrm{mg}$ of $\mathrm{CaCl}_{2}$. The above process was repeated to bring the synthetic water to an alkalinity of $100 \mathrm{mg} / \mathrm{L}$ and water hardness to $160 \mathrm{mg} / \mathrm{L}$, as $\mathrm{CaCO}_{3}$.

\subsection{Dosing Water with Fractionation Component}

The organic fraction found in most waters containing HPOB is partially made up of proteins. Proteins were obtained from Rhodobactor capsulatus (Rhodopserdomonal capsulatas - old name). R. capsulatas is a purple, non-sulfur 
photosynthetic cyanobacteria that is widely distributed and found in fresh water as well as marine and hypersaline habitats. These cyanobacteria were chosen because they are ubiquitous in water environments. Because these experiments require a natural organic matter precursor for DBP formation, these proteins allow for a direct comparison of environmental influences on DBP formation regardless of region. The cellular membrane proteins were obtained from the University of Missouri Chemistry Department. The stock solution concentration of the proteins was $10 \mathrm{mg} / \mathrm{mL}$ with $10 \mathrm{mmol}$ phosphate and $1 \mathrm{mmol}$ PMSF (a protease inhibitor). TOC analysis was conducted to determine the volume of stock protein solution needed to provide the desired protein dose of $5(+/-1) \mathrm{mg} / \mathrm{L}$ of proteins.

\subsection{Analytical Procedures}

\subsubsection{Chlorine Demand}

After the simulated treatment process, water samples were dosed using $\mathrm{NaOCl}$ to achieve a free chlorine residual of $1.0+/-0.4 \mathrm{mg} / \mathrm{l}$ at the end of the 24 hour incubation period, per the uniform formation condition (UFC) procedure. Chlorine residual measurements were conducted by placing approximately $10 \mathrm{ml}$ of chlorinated sample into a sample vial and then testing by Hach Method 8021 (powder pillow test).

\subsubsection{Disinfection By-Product Formation Potential Kinetics}

Four $125 \mathrm{~mL}$ amber bottles filled with chlorinated sample water at each prescribed $\mathrm{pH}$ were incubated in a dark cabinet for 24,48 , and 72 hours at $20^{\circ} \mathrm{C}$. The free chlorine residual is eliminated in the sample bottle using $10 \mu \mathrm{L}$ of ammonium chloride $\left(\mathrm{NH}_{4} \mathrm{Cl}\right)$ to quench the chlorine and act as a preservative. 
The zero hour samples are separated into two $40 \mathrm{~mL}$ sample vials (one for THM and the other for HAA analysis), which holds $\mathrm{NH}_{4} \mathrm{Cl}$ and is stored at $4^{\circ} \mathrm{C}$ in the dark until the other time-step samples are collected.

After samples are dosed with proteins and chlorine, they are stored in the dark at $20^{\circ} \mathrm{C}$ for 24,48 and 72 hours. After the specified times, the samples are quenched using $\mathrm{NH}_{4} \mathrm{Cl}$ to stop the chlorine from forming any further DBPs. The quenched THM samples are stored, with no headspace, in the dark at $4^{\circ} \mathrm{C}$. The HAA samples are also stored in the dark at $4^{\circ} \mathrm{C}$. After the last sample ( 72 hour) is quenched, both the THM and HAA samples are kept in the dark at $4^{\circ} \mathrm{C}$ until inhouse analysis is performed. The THMs are analyzed using a purge and trap concentrator and then a gas chromatograph-mass spectrophotometer detector (Varian 3800-Saturn 2000) following EPA 8216 method; the HAAs are analyzed using liquid-liquid extraction to concentrate the sample and then a gas chromatograph-electron capture detector (Varian 3800) following EPA 552.2 method.

\subsubsection{TOC, UV-254, SUVA, and Turbidity}

Prior to the samples undergoing the disinfection by-product formation potential kinetics test, the samples are filtered using a $0.45 \mu \mathrm{m}$ filter. Approximately $15 \mathrm{~mL}$ of filtered sample is placed in a $24 \mathrm{~mL}$ vial, which is then covered with parafilm. TOC and DOC are measured on a TOC- $\mathrm{V}_{\mathrm{CPN}}$ analyzer (Shimadzu, Japan). TOC and DOC in each vial were measured three times by the analyzer and then averaged to yield the TOC and DOC readings. TOC is the total 
organic present and DOC is the dissolved organic carbon present, to obtain DOC, the water was filtered through a 0.45 microm filter.

UV-254 absorbance is measured by filling a quartz cuvette with filtered sample water and placed in the holder, where the clear side of the cuvette is perpendicular to the light travel path of the machine (Varian Cary-50, US). Three samples were taken and the average value used for the absorbance at 254 nanometer reading.

SUVA is calculated by taking the ultraviolet absorbance value $\left(\mathrm{cm}^{-1}\right)$ generated by the Varian Cary-50 and dividing it by the DOC value $(\mathrm{mg} / \mathrm{L})$ obtained from the TOC- $\mathrm{V}_{\mathrm{CPN}}$ for DOC concentration. This value is then multiplied by $100 \mathrm{~cm} / \mathrm{m}$ to put SUVA in units of $(\mathrm{L} /(\mathrm{mg} * \mathrm{~m}))$.

TOC, DOC and UV-254 absorbance procedures may be found in EPA Method 415.3.

Settled turbidity is measured after the 30 minute settling period is complete, but prior to filtration. To measure turbidity a $15 \mathrm{~mL}$ sample of source water is transferred to the test vial, the vial is then placed in the turbidity meter (Turbidimeter, 2100P, Hach, Colorado). Three samples are taken and the average value is used for documentation. The turbidity test procedure may be found in EPA Method 180.1.

\subsection{Data Analysis}

In order to understand the influence of water quality on DBPs, TOC, DOC, UV-254 and turbidity are plotted as a function of chlorine incubation time. 
This approach is performed for variable $\mathrm{pH}$ (set 1), variable alkalinity (set 2), and variable hardness (set 3).

The data were evaluated using the statistical analysis student's T-Test in Excel. The formula for the students T-Test used with Equal sample sizes but unequal variances is

$t=\frac{\bar{X}_{1}-\bar{X}_{2}}{s_{\bar{X}_{1}-\bar{X}_{2}}}$, where $s_{\bar{X}_{1}-\bar{X}_{2}}=\sqrt{\frac{s_{1}^{2}}{n_{1}}+\frac{s_{2}^{2}}{n_{2}}}$.

The $t$ value was used with the degrees of freedom to obtain a $p$ value from the $p$ tables for the two-tailed test. A p value less than 0.05 is considered significant.

The Excel equation used was:

$=$ ttest $($ dataset1, dataset2,2,3). (Eqn 14)

Dataset 1 was the water without $\mathrm{pH}$ adjustment and dataset 2 was with the $\mathrm{pH}$ adjusted, " 2 " is representing a two-tailed test and the " 3 " representing unequal variances. The result was the $\mathrm{p}$ value.

For each water parameter (hardness or alkalinity) the $\mathrm{pH}$ adjusted experimental sets were compared to the experimental set without $\mathrm{pH}$ adjustment to determine if there were a significant difference between the two experimental sets based on the different $\mathrm{pH}$ values. Also, the students T-Test was also performed to determine if there was a difference between the two concentrations of alkalinity or hardness for a given $\mathrm{pH}$.

The results of the statistical analysis will allow a determination of which factor(s) contributes more to DBP formation, and whether the surrogate 
parameters i.e., TOC, DOC, UV-254, or SUVA, serve as a valid predictor of DBP formation. 


\section{Chapter 4 Results and Discussion}

In chapter 3 an experimental plan was laid out to evaluate the water parameters in an attempt to discover whether select parameters affect the DBPfp. The parameters tested were alkalinity and hardness at a low and high range. Effects of $\mathrm{pH}$ were also tested.

\subsection{Low Alkalinity Condition Results}

The formation of TTHM under low alkalinity parameter conditions (adjusted by adding $\mathrm{NaHCO}_{3}$ to achieve an alkalinity of $100 \mathrm{mg} / \mathrm{L}$ as $\mathrm{CaCO}_{3}$ ) was evaluated without any $\mathrm{pH}$ adjustment, and then with $\mathrm{pH}$ adjusted to 7.5, 8.75, and 10.0 (Figure 4.1).

Low alkalinity TTHM formation in listed in Table 4.1.

Table 4.1 Low Alkalinity TTHMfp at various $\mathrm{pH}$ in $\mu \mathrm{g} / \mathrm{L} / \mathrm{hr}$

\begin{tabular}{|c|c|c|c|}
\hline $\begin{array}{c}\text { No pH Adjustment } \\
(\mathrm{pH} \mathrm{8.13)}\end{array}$ & $\mathrm{pH} \mathrm{7.5}$ & $\mathrm{pH} \mathrm{8.75}$ & $\mathrm{pH} \mathrm{10.0}$ \\
\hline 0.90 & 1.55 & 1.78 & 6.26 \\
\hline
\end{tabular}

On the following graph, each $\mathrm{pH}$ value is listed with the associated DBP formation at $0,24,48$, and 72 hours. The ordinate shows the TTHMs in $\mu \mathrm{g} / \mathrm{L}$ and the abscissa lists the time in hours. The legend indicates the $\mathrm{pH}$ values in question. The graph shows that the average values for no $\mathrm{pH}$ adjustment ( $\mathrm{pH} 8.13$ ), $\mathrm{pH} 7.5$, and $\mathrm{pH} 8.75$ are very similar, within one standard deviation, while $\mathrm{pH} 10.0$ is markedly above the rest of the values. It is likely that the rate of TTHM increase at $\mathrm{pH} 10.0$ is due to the behavior of the NOM itself. Proteins will be relatively un-reactive until they reach their $\mathrm{pKa}$ range, Histidine at 7.58, Lysine at 10.0, Cysteine 8.5, and Tyrosine 10.0. The pKa value is the point where the proteins no longer exhibit a net zero charge and will lose their natural globular state and start to unfold to expose the hydrophobic beta layer (personal 
communication with Dr. Emrich, 2014). This layer exposes more contact surface area, which would allow more binding sites for the disinfectant and thus create more DBPs.

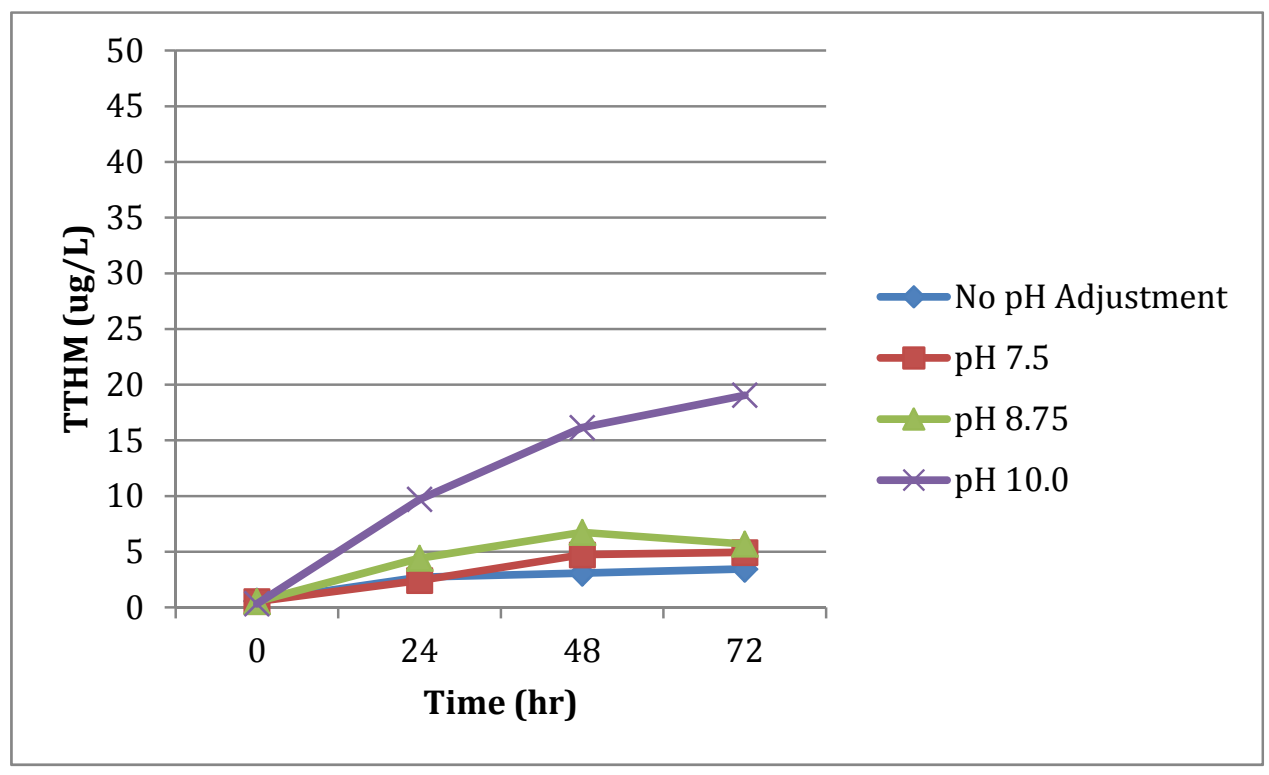

Figure 4.1 TTHMfp under Low Alkalinity $\left(100 \mathrm{mg} / \mathrm{L}\right.$ as $\left.\mathrm{CaCO}_{3}\right)$ conditions - All $\mathrm{pH}$ Ranges

\subsection{High Alkalinity Condition Results}

TTHM formation potential under High Alkalinity conditions $(155 \mathrm{mg} / \mathrm{L}$ as $\mathrm{CaCO}_{3}$ ) was evaluated to determine whether there was any benefit in increasing the alkalinity in an effort to reduce DBPfp (Figure 4.2). Because alkalinity is the ability of a solution to neutralize acid conditions, the $\mathrm{pH} 7.5$ jars required the addition of sufficient acid to lower the $\mathrm{pH}$ from the initial value of $\mathrm{pH} 8.26$. Under the High Alkalinity condition, alkalinity TTHM formation in listed in Table 4.2.

Table 4.2 High Alkalinity TTHMfp at various $\mathrm{pH}$ in $\mu \mathrm{g} / \mathrm{L} / \mathrm{hr}$

\begin{tabular}{|c|c|c|c|}
\hline $\begin{array}{c}\text { No } \mathrm{pH} \text { Adjustment } \\
\text { (pH 8.23) }\end{array}$ & $\mathrm{pH} \mathrm{7.5}$ & $\mathrm{pH} \mathrm{8.75}$ & $\mathrm{pH} 10.0$ \\
\hline 0.09 & 0.01 & 0.01 & 0.21 \\
\hline
\end{tabular}

When comparing low alkalinity to high alkalinity conditions, the formation potential observed consistently lower for the high alkalinity conditions for all of the $\mathrm{pH}$ 
conditions. There is approximately a $5 \mu \mathrm{g} / \mathrm{L}$ decrease at each time step for $\mathrm{pH} 10$. Again, this increase in DBPs at $\mathrm{pH} 10$ is probably due to the unfolding of the proteins at the $\mathrm{pH}$.

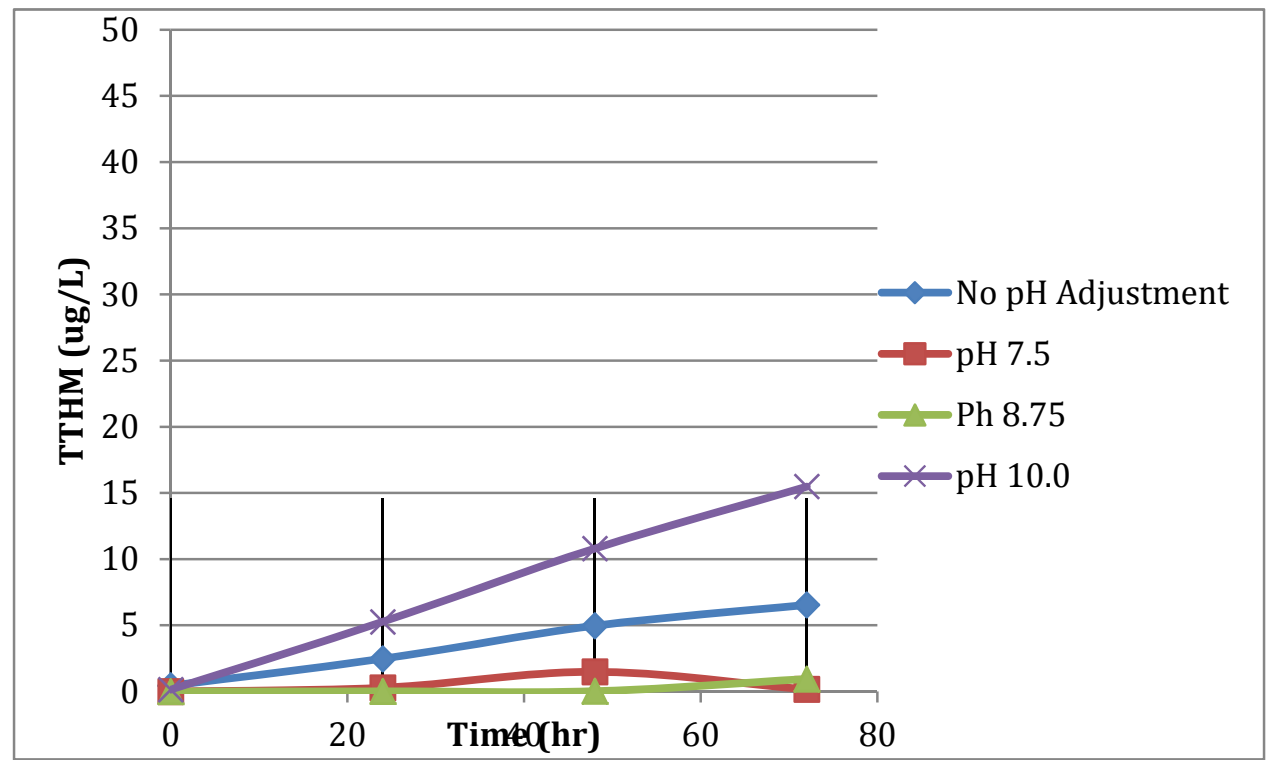

Figure 4.2 TTHMfp under High Alkalinity $\left(155 \mathrm{mg} / \mathrm{L}\right.$ as $\left.\mathrm{CaCO}_{3}\right)$ conditions - All pH Ranges

Figures 4.3 through 4.6 show that the DBP concentration over the 72 -hour period for the waters without $\mathrm{pH}$ adjustment, adjusted to $\mathrm{pH} 7.5$, and adjusted to $\mathrm{pH} 8.75$ are all within one standard deviation of each other. At $\mathrm{pH} 10.0$ there is a significant increase $(\mathrm{p}<0.05)$ from the other $\mathrm{pH}$ test runs within the testing parameter. 


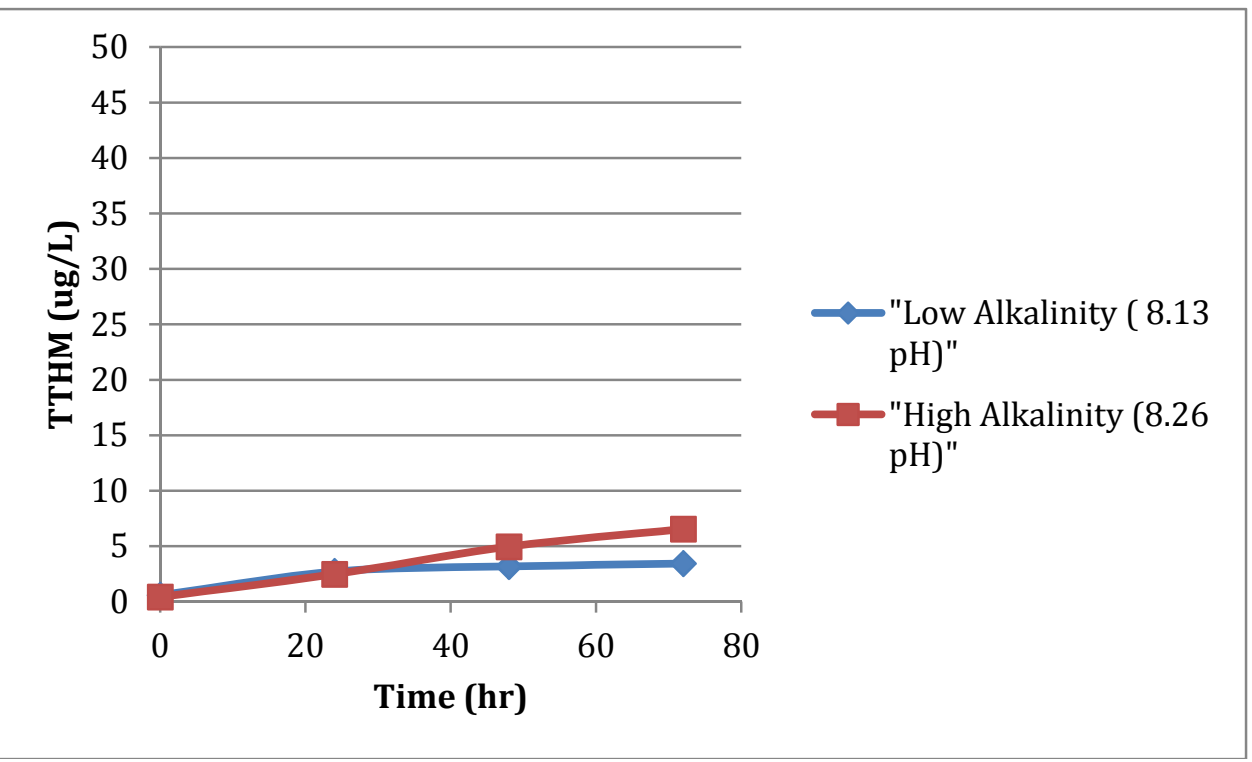

Figure 4.3 TTHM for Low and High Alkalinity, No pH adjustment

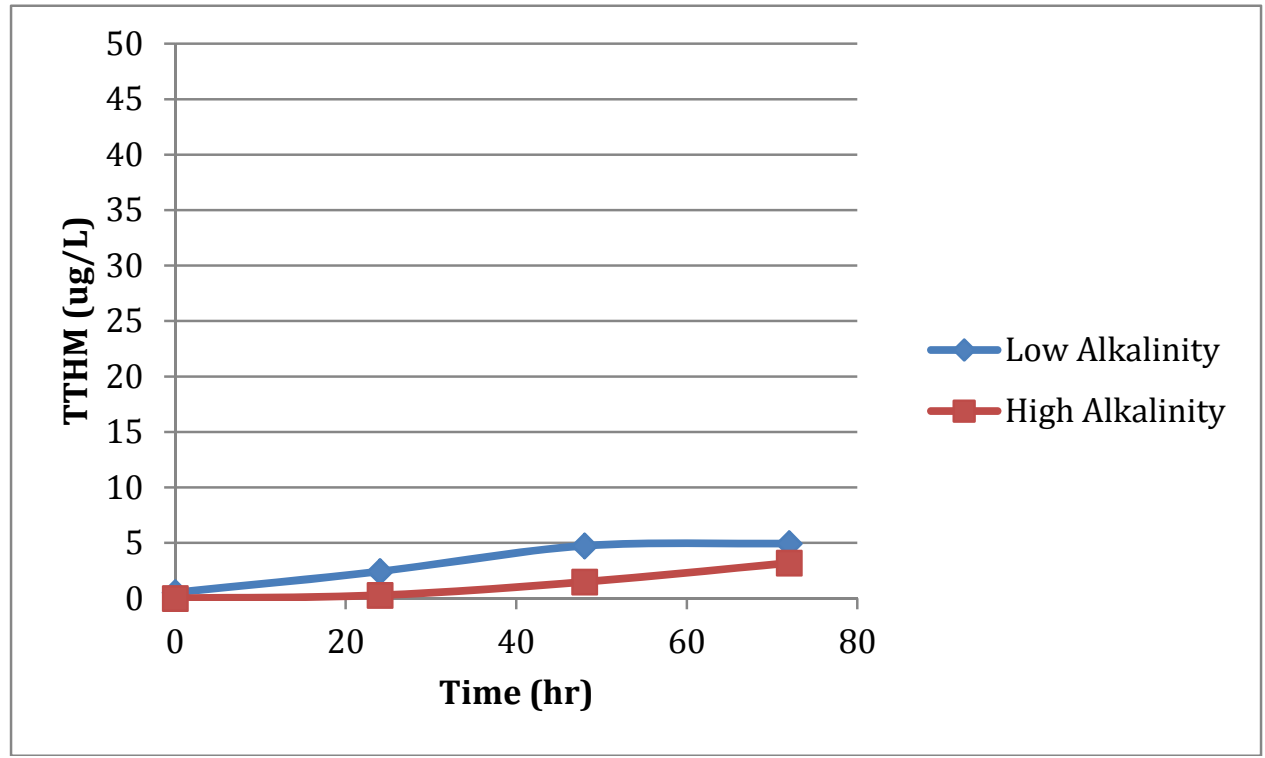

Figure 4.4 TTHM for Low and High Alkalinity, pH 7.5 


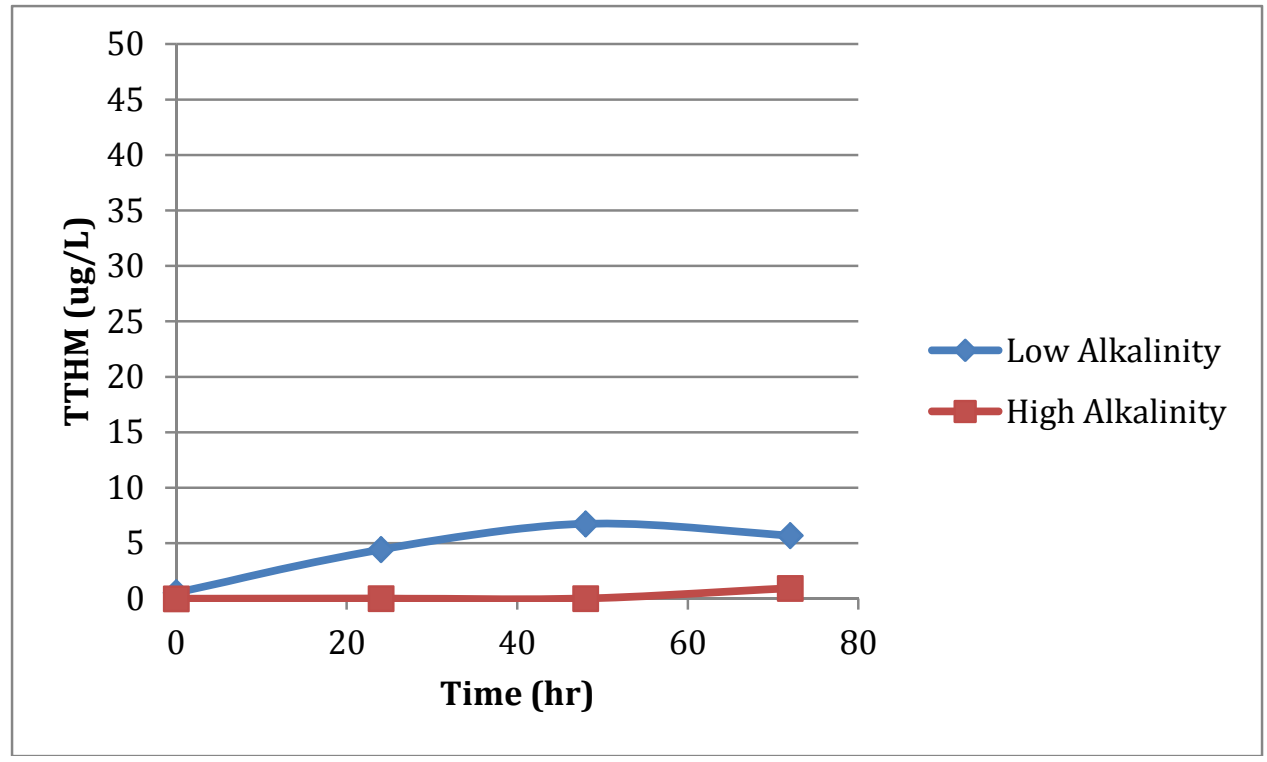

Figure 4.5 TTHM for Low and High Alkalinity, $\mathrm{pH} 8.75$

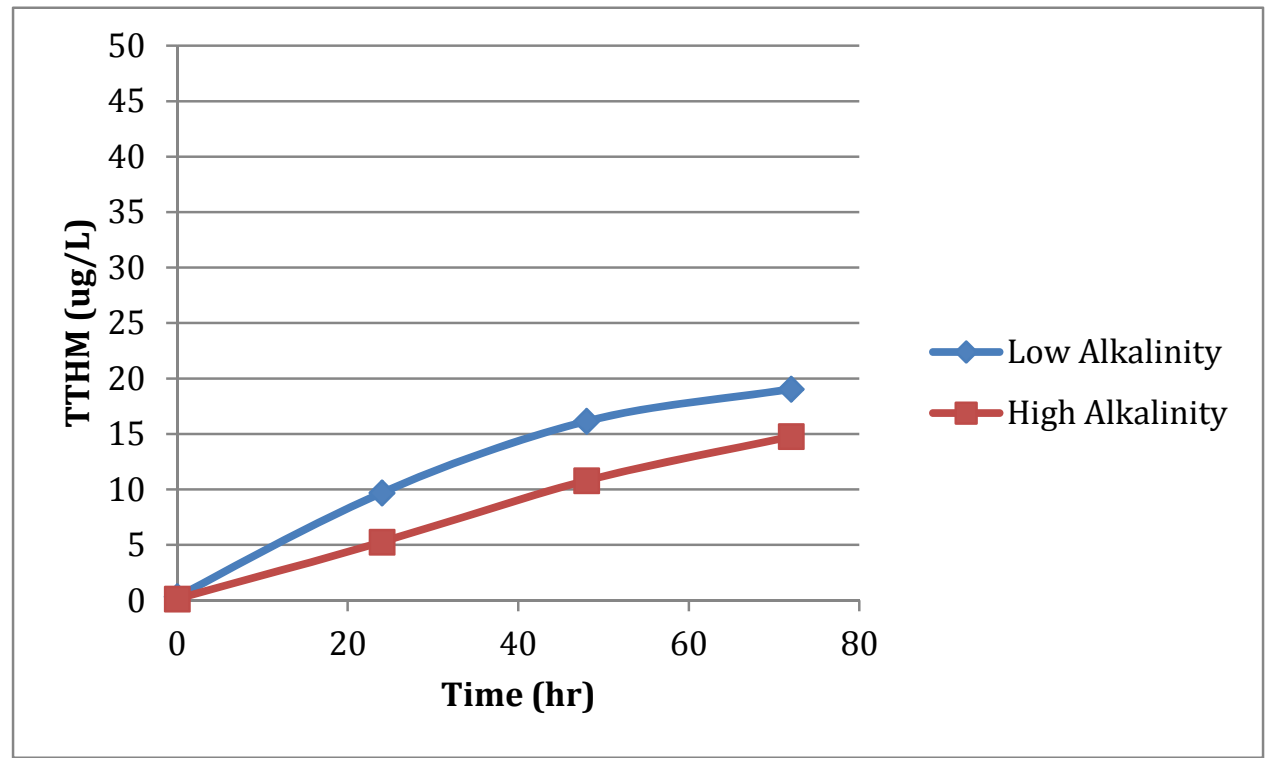

Figure 4.6 TTHM for Low and High Alkalinity, pH 10.0

However, between the two test parameters, the TTHMs are approximately within $5 \mu \mathrm{g} / \mathrm{L}$ of each other regardless of the $\mathrm{pH}$ under consideration. Based upon these data there does not seem to be much difference between low alkalinity and high alkalinity in limiting the DBPfp. However, using the Students t-test, it was found there was a significant difference between all the $\mathrm{pH}$ values between Low Alkalinity and High 
Alkalinity when comparing each individual $\mathrm{pH}$ range with the High Alkalinity generating less TTHMs.

\subsection{Low Hardness Condition Results}

The other water parameter evaluated was water hardness. Water hardness is considered an aesthetic quality and limited testing has been done relating to whether it is a factor in DBPfp. Figure 4.7 shows the result of DBPs formed in low water hardness (adjusted by adding $\mathrm{CaCl}_{2}$ to achieve a hardness of $100 \mathrm{mg} / \mathrm{L}$ as $\mathrm{CaCO}_{3}$ ) under the various $\mathrm{pH}$ ranges.

With no $\mathrm{pH}$ adjustment the formation of TTHM under the Low Hardness condition is given in Table 4.3 .

Table 4.3 Low Hardness TTHMfp at various $\mathrm{pH}$ in $\mu \mathrm{g} / \mathrm{L} / \mathrm{hr}$

\begin{tabular}{|c|c|c|c|}
\hline $\begin{array}{c}\text { No pH Adjustment } \\
(\mathrm{pH} \mathrm{6.03)}\end{array}$ & $\mathrm{pH} \mathrm{7.5}$ & $\mathrm{pH} \mathrm{8.75}$ & $\mathrm{pH} \mathrm{10.0}$ \\
\hline 0.10 & 0.07 & 0.11 & 0.48 \\
\hline
\end{tabular}

Figure 4.7 DBP values are similar except $\mathrm{pH} 7.5$ peaks at the 24 hour mark and $\mathrm{pH} 8.75$ peaks at 48 hours, the indicated $\mathrm{pH}$ seems to have an interaction on the rate of TTHM formation. At $\mathrm{pH} \mathrm{10,} \mathrm{the} \mathrm{concentration} \mathrm{of} \mathrm{DBPs} \mathrm{increases,} \mathrm{this} \mathrm{increase} \mathrm{may} \mathrm{be}$ due to the unfolding of the proteins as well as an absence of a buffer (alkalinity) to limit any potential formation due to changes in $\mathrm{pH}$ caused by the protein/disinfectant interaction. 


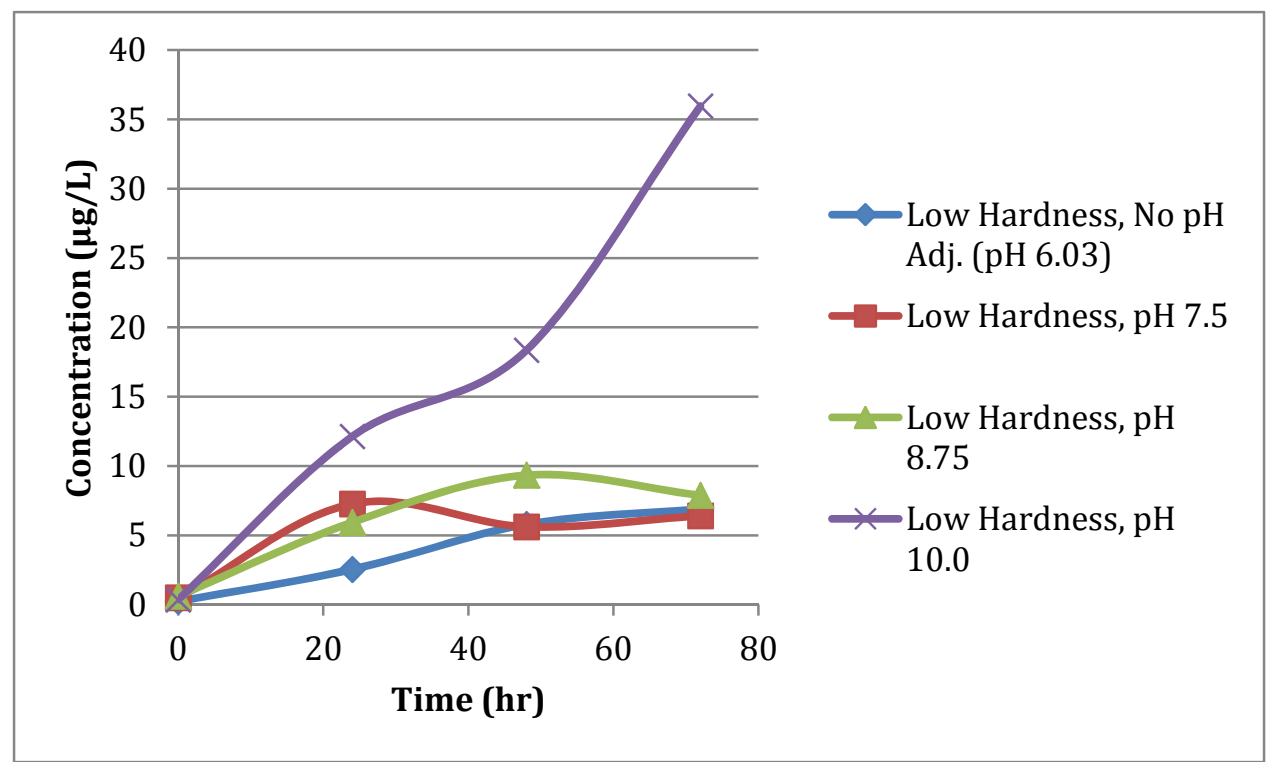

Figure 4.7 TTHMfp under Low Hardness $\left(100 \mathrm{mg} / \mathrm{L}\right.$ as $\left.\mathrm{CaCO}_{3}\right)$ conditions - All pH Ranges

\subsection{High Hardness Condition Results}

High water hardness $\left(160 \mathrm{mg} / \mathrm{L}\right.$ as $\left.\mathrm{CaCO}_{3}\right)$ was evaluated as well. With no $\mathrm{pH}$ adjustment the formation of TTHM under the High Hardness condition is listed in Table

\section{4 .}

Table 4.4 High Hardness TTHM $f p$ at various $\mathrm{pH}$ in $\mu \mathrm{g} / \mathrm{L} / \mathrm{hr}$

\begin{tabular}{|c|c|c|c|}
\hline $\begin{array}{c}\text { No pH Adjustment } \\
(\mathrm{pH} \mathrm{6.17)}\end{array}$ & $\mathrm{pH} \mathrm{7.5}$ & $\mathrm{pH} \mathrm{8.75}$ & $\mathrm{pH} \mathrm{10.0}$ \\
\hline 0.09 & 0.08 & 0.12 & 0.28 \\
\hline
\end{tabular}

The High Hardness tests behaved as the others, the DBPs formed stayed consistent over the $\mathrm{pH}$ ranges until $\mathrm{pH} 10.0$. At $\mathrm{pH} 10.0$ there was an increase in the amount of DBPs formed. This increase is probably due to the unfolding of the protein at the higher $\mathrm{pH}$ and perhaps a lack of buffer to reduce the $\mathrm{pH}$ effects of the protein/disinfectant. 


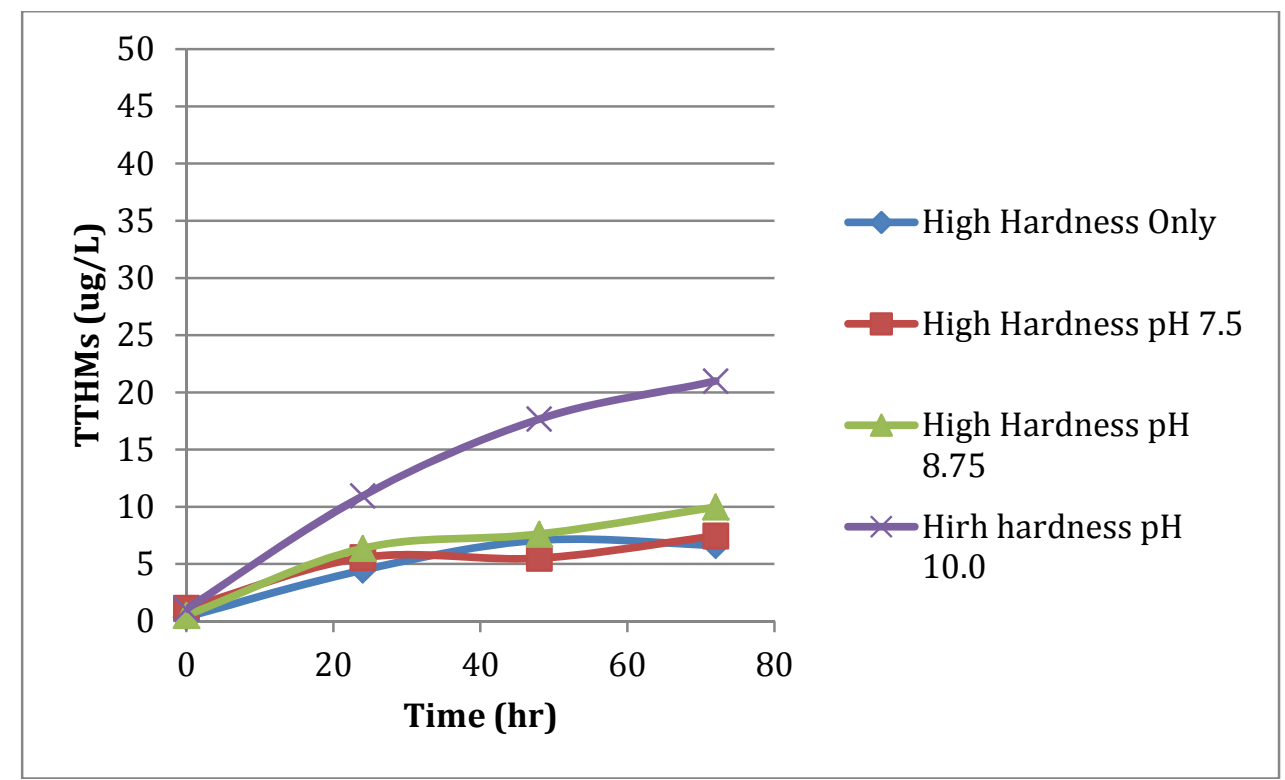

Figure 4.8 TTHMfp under High Hardness $\left(160 \mathrm{mg} / \mathrm{L}\right.$ as $\left.\mathrm{CaCO}_{3}\right)$ conditions - All pH Ranges

Comparing Figures 4.7 and 4.8, it would appear at $\mathrm{pH}$ ranges below 10.0, the Low Hardness and High Hardness are virtually the same. At pH 10.0, for either concentration, the unfolding of the proteins allows more interaction with the disinfectant allowing more DBPs to form. When comparing, using the students t-test, the Low Hardness to the High Hardness tests, only pH 7.5 was not a significant difference $(\mathrm{p}>0.05)$. The rest of the $\mathrm{pH}$ comparisons between the two hardness concentrations were significantly different $(\mathrm{p}$ $<0.05$ ). Figure 4.7, for $\mathrm{pH} 10.0$, shows a concentration of TTHMs to be approximately $36 \mathrm{ug} / \mathrm{L}$ after 72 hours of incubation time, while Figure 4.8 shows a concentration of approximately $22 \mathrm{ug} / \mathrm{L}$ for the same incubation period. The parameter of High Hardness, at $\mathrm{pH} 10.0$, allows less DBPs to form. This apparent $14 \mathrm{ug} / \mathrm{L}$ decrease may be due to the increased calcium in the water and precipitating out of solution at $\mathrm{pH} 10.0$. This precipitation would allow an increase in the amount of free $\mathrm{Ca}^{2+}$ cations present that would be available to attract the negative charged proteins. This interaction would have the result of decreasing the amount of NOM available to interact with the disinfectant. 
This increased interaction between the calcium and proteins would also result in larger flocs, which would then settle out of the water column.

Figures 4.9 through 4.12 shows the comparisons between Low Hardness and High hardness for each of the $\mathrm{pH}$ ranges evaluated.

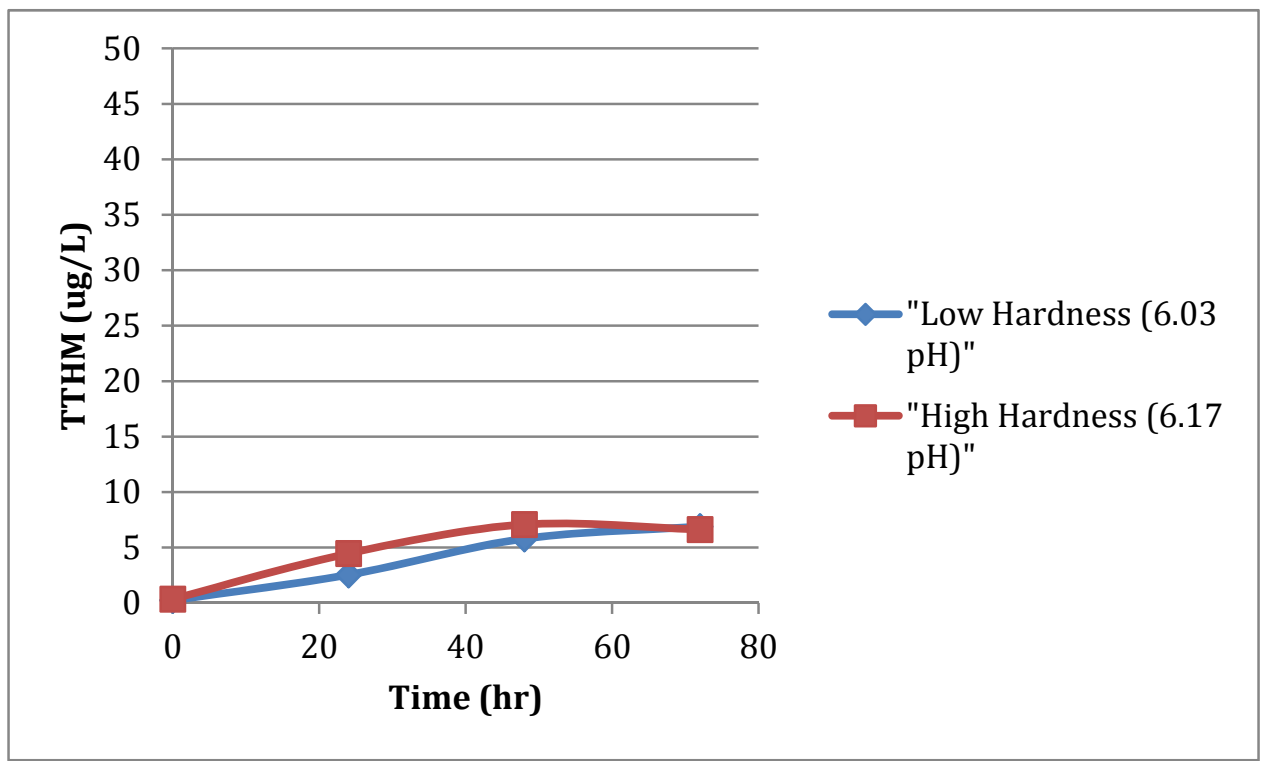

Figure 4.9 TTHM for Low and High Hardness, No pH adjustment

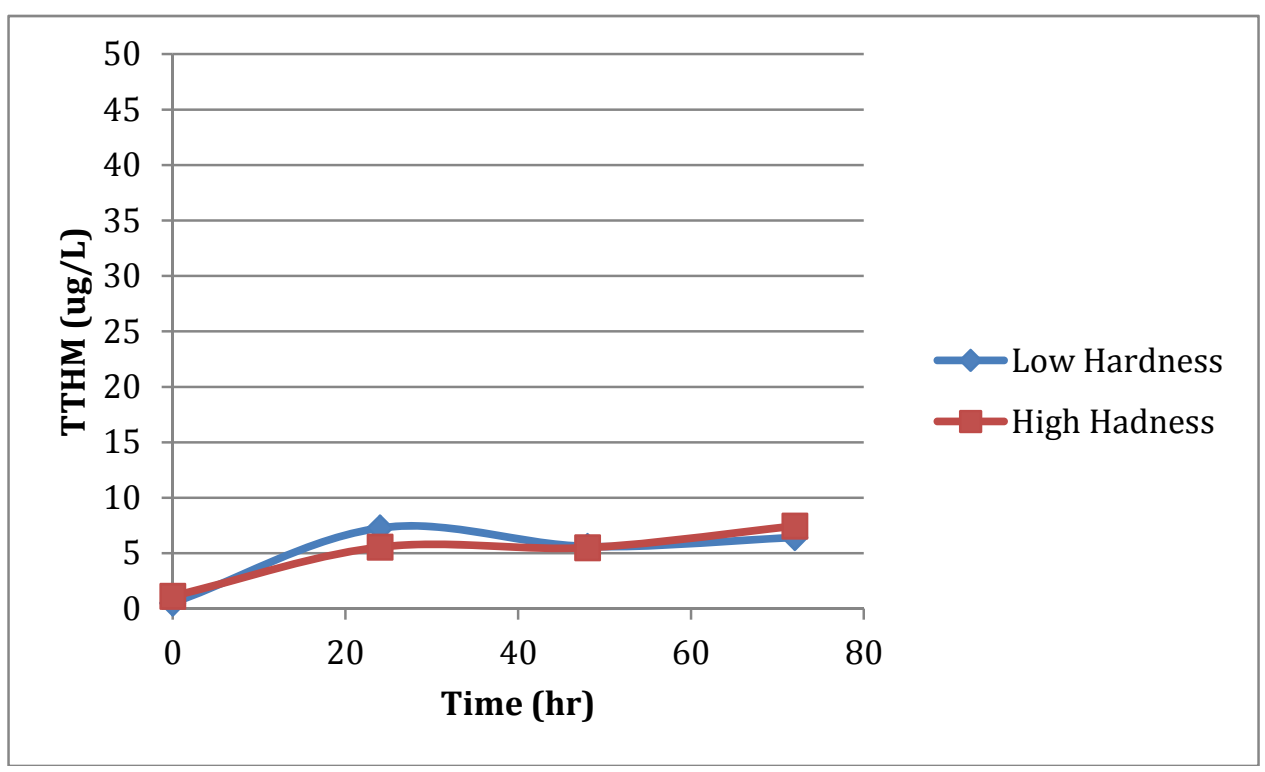

Figure 4.10 TTHM for Low and High Hardness, pH 7.5 


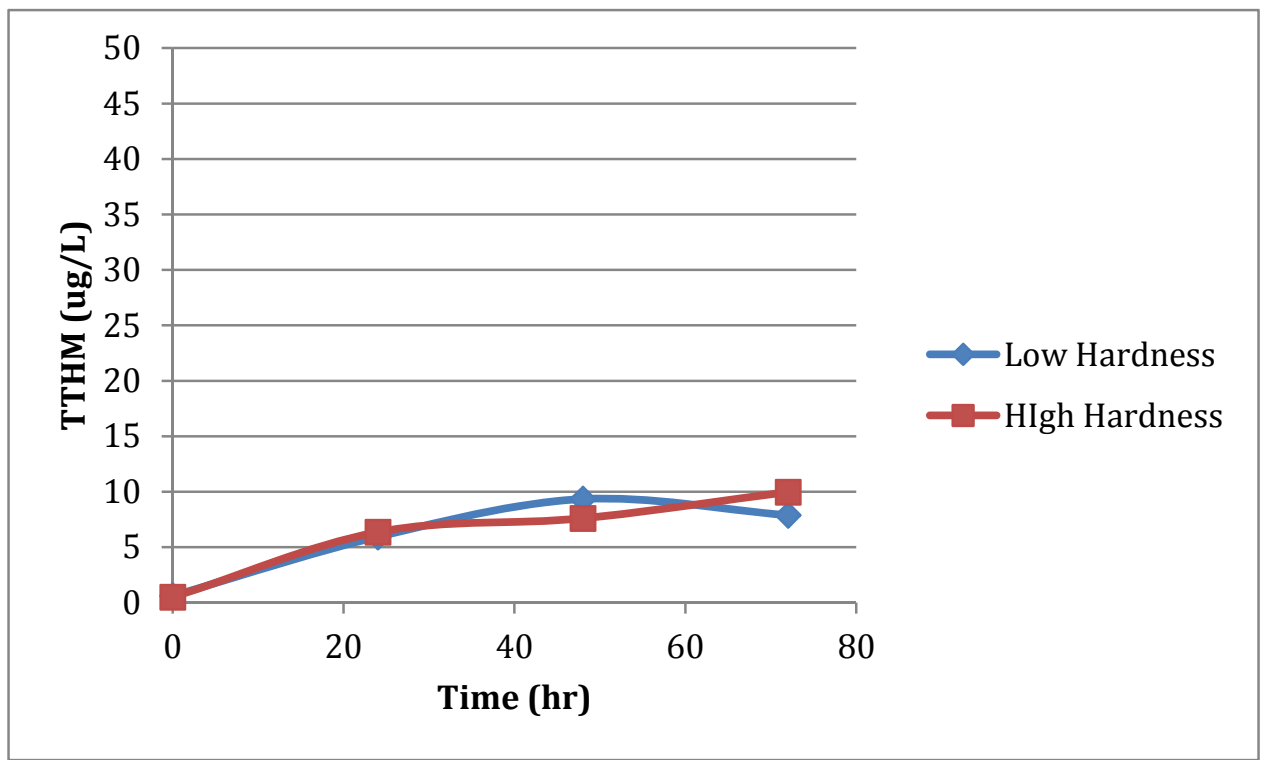

Figure 4.11 TTHM for Low and High Hardness, pH 8.75

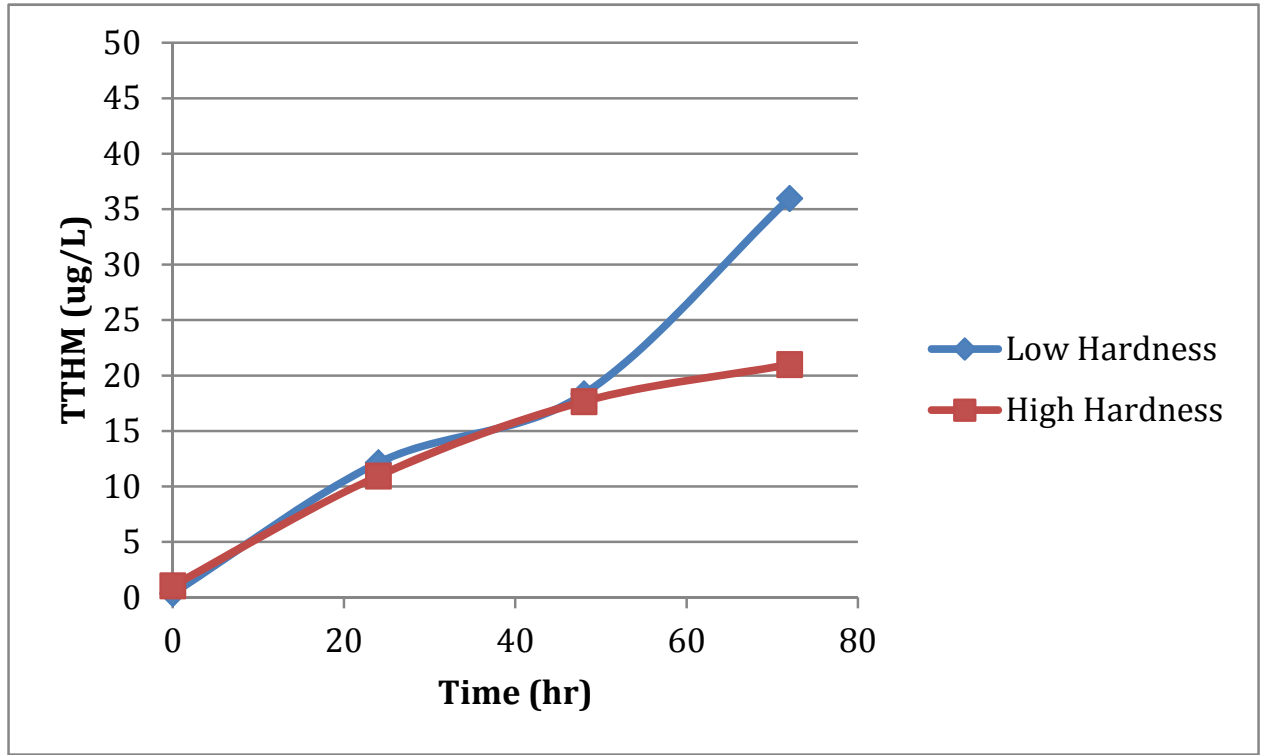

Figure 4.12 TTHM for Low and High Hardness, $\mathrm{pH} 10.0$

\subsection{Global Mean Values}

The global mean value alkalinity $(155 \mathrm{mg} / \mathrm{L})$ and hardness $(100 \mathrm{mg} / \mathrm{L})$ was tested and compared against the other parameters in an attempt to determine if alkalinity and hardness were a factor in DBPfp. The results are shown in table 4.5. 
Table 4.5 Global Mean Values TTHM $f p$ at various $\mathrm{pH}$ in $\mu \mathrm{g} / \mathrm{L} / \mathrm{hr}$

\begin{tabular}{|c|c|c|c|}
\hline $\begin{array}{c}\text { No pH Adjustment } \\
\text { (pH 8.27) }\end{array}$ & $\mathrm{pH} \mathrm{7.5}$ & $\mathrm{pH} \mathrm{8.75}$ & $\mathrm{pH} 10.0$ \\
\hline 0.13 & 0.12 & 0.14 & 0.56 \\
\hline
\end{tabular}

For the global mean values, the TTHM concentration appears to be additive; at $\mathrm{pH} 10.0$ the alkalinity at the global mean value of $155 \mathrm{mg} / \mathrm{L}$ as $\mathrm{CaCO}_{3}$, had a mean value of approximately $20 \mathrm{ug} / \mathrm{l}$ and hardness at the global mean value of $100 \mathrm{mg} / \mathrm{L}$ as $\mathrm{CaCO}_{3}$, had a mean value around $25 \mathrm{ug} / \mathrm{L}$. Figure 4.13 shows the TTHMs for the global mean value water (Alkalinity $155 \mathrm{mg} / \mathrm{L}$, Hardness $100 \mathrm{mg} / \mathrm{L}$ ) to be approximately $42 \mathrm{ug} / \mathrm{L}$ at $\mathrm{pH}$ 10.0. The other $\mathrm{pH}$ ranges demonstrated similar values as the other tests for all the other $\mathrm{pH}$ ranges tested.

This apparent addition would seem to indicate the water parameters are independent on one another and treatment processes should concentrate on the parameter that would be the most beneficial in reducing DBPfp. In this study, the parameters having the overall lowest TTHMfp were with High Alkalinity $\left(155 \mathrm{mg} / \mathrm{L}\right.$ as $\left.\mathrm{CaCO}_{3}\right)$ and Low Hardness $\left(100 \mathrm{mg} / \mathrm{L}\right.$ as $\left.\mathrm{CaCO}_{3}\right)$ at the lower $\mathrm{pH}$ values. At $\mathrm{pH}$ 10, High Alkalinity with High Hardness $\left(160 \mathrm{mg} / \mathrm{L}\right.$ as $\left.\mathrm{CaCO}_{3}\right)$ may be favored due to the calcium precipitation that occurs. 


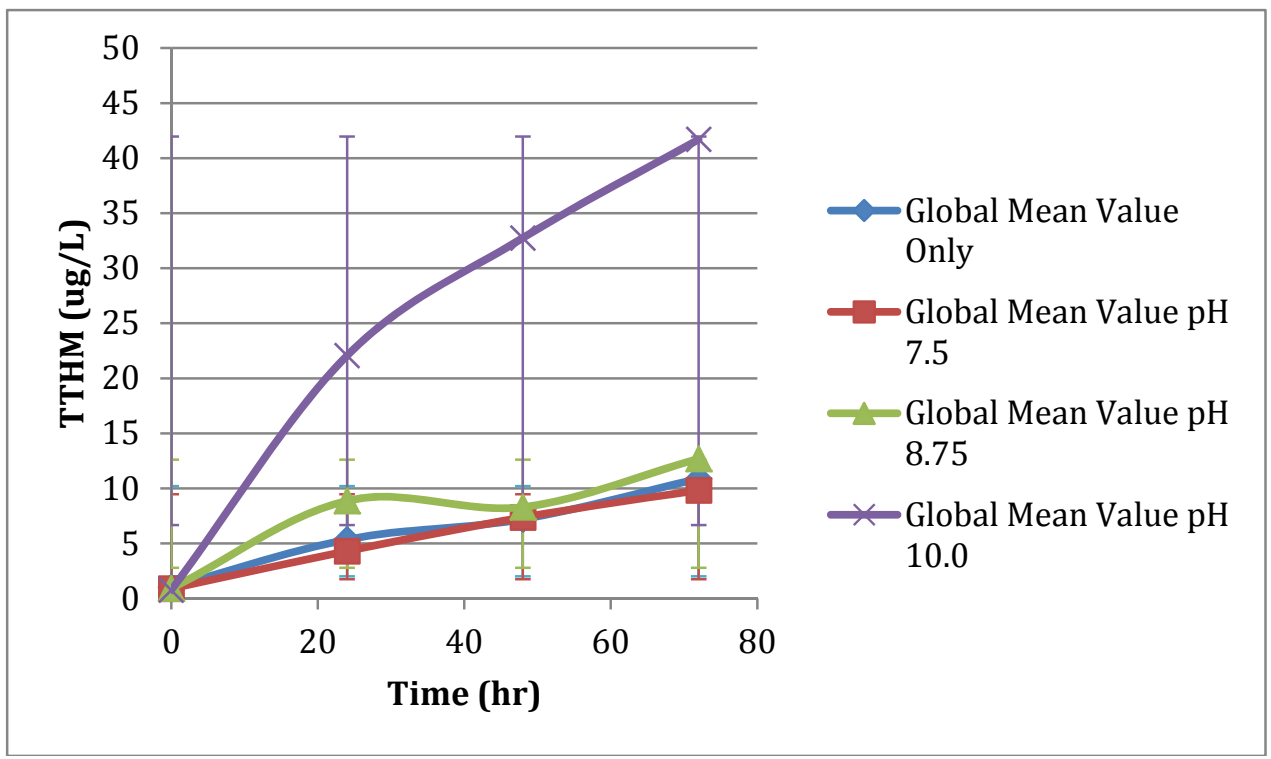

Figure 4.13 Global Mean Values - All pH Ranges

\subsection{Surrogate Parameter Considerations}

The surrogate parameters, TOC, DOC, SUVA, UV-254, and turbidity, have been used as an indicator of DBPfp. The original experimental plan was to examine each of these to determine if there was a correlation between the surrogate parameter and the actual concentration of DBP formed.

The TOC analyzer was inoperative for some of the experiments; however, from what data were collected there was not a significant effect from the surrogate parameters to predict TTHM formation potential. The actual composition of the DOC may account for the poor correlation between SUVA and UV-254 readings as different organic matter absord at different wavelengths (Fram et al. 1999). If the NOM absorbs at a different wavelength than $254 \mathrm{~nm}$ then the SUVA value, which depends upon the UV-254 value, would be in error and therefore would not provide a correlation between the SUVA and DBPfp. 
Turbidity measurements were analyzed using ANOVA and it was determined that there was not a correlation between turbidity and DBPfp for the data sets. UV-254 was also found to be statistically non-significant indicating the UV-254 measurements could not be used to predict the DBPfp. UV-254 test are useful when dealing with waters containing humic acids which are high in aromatic organic matter that has double bonds in its ring structure (Glover, 2007). Proteins do not have the double bond aromatic ring structure and are less likely to absorb the UV at the $254 \mathrm{~nm}$ wavelength, because the preferred UV wavelength for proteins is $280 \mathrm{~nm}$ (Layne 1957; Stoscheck 1990). For water containing a high concentration of nucleic acids, a wavelength of $260 \mathrm{~nm}$ should be used (Glasel 1995). The different absorbance characteristic wavelength of the proteins used as the NOM source may explain the poor correlation between using UV254 and SUVA as DBP predictors. 


\section{Chapter 5 Conclusion}

\subsection{Research Premise Summary}

This study examined DBPfp due to a change in the source water characteristics, namely hardness, alkalinity, and $\mathrm{pH}$, to determine whether these parameters had any effect on the rate of DBPfp. Any observed differences could inform decisions on what parameter should be changed for a reduction in DBPs.

\subsection{Main Findings}

Environmental water parameters were evaluated under different $\mathrm{pH}$ values to determine whether the parameters had any affect on DBP formation. Synthetic water was produced with Millipore water and then adding $\mathrm{NaHCO}_{3}$ in different doses to change the alkalinity of the water, or by adding $\mathrm{CaCl}_{2}$ to change the hardness.

The DBPfp was evaluated with alkalinity at $100 \mathrm{mg} / \mathrm{L}$ and $155 \mathrm{mg} / \mathrm{L}$ as $\mathrm{CaCO}_{3}$ and water hardness at $100 \mathrm{mg} / \mathrm{L}$ and $160 \mathrm{mg} / \mathrm{L}$ as $\mathrm{CaCO}_{3}$. The global mean values were $155 \mathrm{mg} / \mathrm{L}$ for alkalinity and $100 \mathrm{mg} / \mathrm{L}$ for hardness.

Table 5.1 details the TTHM concentration $(\mu \mathrm{g} / \mathrm{L})$ levels for each of the tested water parameters.

Table 5.1 Concentration $(\mu \mathrm{g} / \mathrm{L})$ of TTHM after 72 hour Incubation Period

\begin{tabular}{|l|l|l|l|l|l|}
\hline & $\begin{array}{l}\text { Low } \\
\text { Alkalinity }\end{array}$ & $\begin{array}{l}\text { High } \\
\text { Alkalinity }\end{array}$ & $\begin{array}{l}\text { Low } \\
\text { Hardness }\end{array}$ & $\begin{array}{l}\text { High } \\
\text { Hardness }\end{array}$ & $\begin{array}{l}\text { Global Mean } \\
\text { Values }\end{array}$ \\
\hline $\begin{array}{l}\text { No pH } \\
\text { Adjustment }\end{array}$ & 3.44 & 6.55 & 6.89 & 6.62 & 13.44 \\
\hline pH 7.5 & 4.92 & 0.19 & 6.42 & 7.44 & 6.61 \\
\hline pH 8.75 & 5.79 & 1.53 & 7.89 & 10.06 & 8.83 \\
\hline pH 10.0 & 19.05 & 4.53 & 35.96 & 20.99 & 39.44 \\
\hline
\end{tabular}


Between the two alkalinity concentrations, the high alkalinity produced an overall lower concentration of TTHMs; it is suspected this is due to the suppression of any $\mathrm{pH}$ related chemical reactions taking place during DBP formation.

Milipore water then tested under solely hardness conditions. For the low hardness level $\left(100 \mathrm{mg} / \mathrm{L}\right.$ as $\left.\mathrm{CaCO}_{3}\right)$, the TTHMs at the lower $\mathrm{pH}$ values were overall less than those of the high hardness $(160 \mathrm{mg} / \mathrm{L})$ waters. However, at $\mathrm{pH} 10$ the high hardness water produced a lower concentration of TTHMs. The higher concentration of $\mathrm{CaCl}_{2}$ would allow more $\mathrm{Ca}^{2+}$ cations to precipitate out and combine with the negatively charged proteins and form larger flocs thereby allowing less organic matter to remain to react with the disinfectant. If the amount of NOM is reduced, then there should also be a decrease in the amount of disinfectant required thereby decreasing the amount of DBP formed. Traditionally the NOM reduction has been achieved through adding coagulants, settling, and filtration.

The results shown in Table 5.1 suggest waters with high alkalinity and high hardness at $\mathrm{pH} 10.0$ would form relatively lower THM concentrations than waters that have low alkalinity or low hardness at the same $\mathrm{pH}$. This proposed preferred water quality with alkalinity at $155 \mathrm{mg} / \mathrm{L}$ and hardness at $100 \mathrm{mg} / \mathrm{L}$ is indicative of a groundwater coming from a karst aquifer. The observations also suggest treatment approaches, which may be taken by surface water systems in an attempt to reduce their TTHMfp.

Based upon the above TTHM concentrations for alkalinity at $155 \mathrm{mg} / \mathrm{l}$ and hardness at $100 \mathrm{mg} / \mathrm{L}$, the global mean value water (alkalinity $155 \mathrm{mg} / \mathrm{L}$ and hardness $100 \mathrm{mg} / \mathrm{L}$ ) should produce a similar TTHM concentration near those obtained by each 
parameter separately. However, it was found the TTHM concentration result seems to be an addition between the two. The addition of the alkalinity and hardness TTHM values would imply the mechanisms of THM formation are independent of one another with each parameter allowing an alternate path to THM formation.

If the addition property is valid, then one could see a potential reduction of THMs formed by adjusting the source water. In this study it was determined there would be a slight decrease in TTHMfp with an increase in alkalinity to $155 \mathrm{mg} / \mathrm{L}$ at the lower $\mathrm{pH}$ values. However, at $\mathrm{pH} 10$, with the hardness at $160 \mathrm{mg} / \mathrm{L}$ and alkalinity at $155 \mathrm{mg} / \mathrm{L}$, there would be approximately a $15 \mu \mathrm{g} / \mathrm{L}$ decrease in TTHM formed after a 72 hour time period compared to water with the lower hardness concentration of $100 \mathrm{mg} / \mathrm{L}$ at $\mathrm{pH} 10$. 


\section{Chapter 6 Future Considerations}

Based on the preliminary findings of this study, it seems to be possible to lower the THMfp by increasing alkalinity. If the water were treated at $\mathrm{pH} 10.0$, then increasing the hardness may provide a reduction in TTHMfp as well. It is recommended that a natural source water, either surface or ground, should be obtained and THM analysis run to try to replicate these findings with natural water. Surface water typically has a hardness of $90 \mathrm{mg} / \mathrm{L}$ as $\mathrm{CaCO}_{3}$ and alkalinity of $100 \mathrm{mg} / \mathrm{L}$ as $\mathrm{CaCO}_{3}($ Qasim, et al., 2000). These values would correspond to the synthetic water as low hardness and low

alkalinity. A typical groundwater has hardness and alkalinity concentrations of 120 and $150 \mathrm{mg} / \mathrm{L}$ as $\mathrm{CaCO}_{3}$ (Qasim, et al., 2000), respectively. These values would correspond to the experimental test conditions of low hardness and high alkalinity. It would be expected by adjusting the alkalinity and/or hardness, as well as the $\mathrm{pH}$ of the natural source water that there would be a decrease in the amount of DBPs formed.

Additionally, several UV wavelengths should be evaluated to determine which wavelength provides the greatest absorption. Wavelengths of $254 \mathrm{~nm}$ for aromatic compounds, 260, and $280 \mathrm{~nm}$ for nucleic acids and proteins, should be evaluated to determine the greatest absorbance (Glover, 2007; Layne, 1957, Stoscheck, 1990).

Table 6.1 lists substances with the UV wavelength at which they absorb. 
Table 6.1 UV wavelength peaks for a given substance (modified from Nakahara, 2002)

\begin{tabular}{|l|l|}
\hline Substance & Absorption Peak $(\mathrm{nm})$ \\
\hline Ethylene $\left(\mathrm{CH}_{2}=\mathrm{CH}_{2}\right)$ & 180 \\
\hline 1.3-butadine & 217 \\
\hline Vitamin A & 328 \\
\hline B-carotene & 450 \\
\hline Benzene & 255 \\
\hline Naphthalene & 286 \\
\hline Anthracene & 375 \\
\hline Naphthacene & 477 \\
\hline
\end{tabular}

Different substances absorb at different wavelengths and the wavelength that provides the greatest absorbance is the wavelength that should then be used in determining SUVA values.

Performing a fractionation study may be beneficial as one would then know what components were in the water, this would then suggest which UV wavelength would provide the appropriate level of absorbance. 


\section{References}

California State University - Northridge, 2011 URL:

http://www.csun.edu/ vchsc006/356b/chlorine.html

Christman K., (1998) The history of chlorine, Waterworld 14: page 66-67

Chlorine, (2012) Chemicool Periodic Table. Chemicool.com. Web. 6/2/2014

URL:http:/www.chemicool.com/elements/chlorine.html

Consonery, P., (2004) Getting the Most Out of Your TOC Information. AWWA Opflow

Craun, M.F., Craun, G.F., Calderon, R.L., and Beach, M.J., (2006) Waterborne outbreaks reported in the United States. Journal of Water and Health, 04 Suppl 2

Crebelli, R., Conti, L., Monarca, S., Feretti, D., Zerbini, I., Zani, C., Veschetti, E., Cutilli, D., and Ottaviani, M., (2005) Genotoxicity of the disinfection by=products resulting from peracetic acid- or hypochlorite-disinfectied sewage waters. Water research 39, 1105-1113

Diehl, A., (2012), URL:

http://upload.wikimedia.org/wikipedia/commons/e/ef/Chloramination_breakpoint_curve \%28theoretical\%29.jpg

Enzler, S.M., History of Water Treatment. Significant Historical Events Forming the Basis for Today's Water Treatment Systems. URL:http://www.lenntech.com/historywater-treatment.htm\#ixzz30tgqvbry

Evans, P., (2010) Nature Works Biological Treatment Methods Yield High-Quality Water. AWWA Opflow

Excel Water Technologies (2007) The History of Drinking Water Treatment

Fram, M. S.; Fujii, R.; Weishaar, J. L.; Bergamaschi, B. A.; Aiken, G., (1999) How DOC Composition May Explain the Poor Correlation Between Specific Trihalomethane Formation Potential and Specific UV Absorbance; Water-Resources Investigations Report 99-4018B; Charleston, SC,; pp 423-430

Glasel J., (1995) "Validity of nucleic acid purities monitored by 260/280 absorbance ratios". BioTechniques 18 (1): 62-63

Greenway Environmental Laboratories. Accessed 4/1/14, www.greenwayeng.com

Grigorescu, A.S. and Hozalski, R.M., (2010) Modeling HAA biodegradation in biofilters and distribution systems. Journal American Water Works Association 102(7), 67-80. 
Hoxie, N.J., et al. (1997) "Cryptosporidiosis-Associated Mortality Following a Massive Waterbome Outbreak in Milwaukee, Wisconsin", American Journal of Public Health 87 (12): 2032-2035

Hozalski, R.M., Zhang, P., LaPara, T.M., Grigorescu, A., Leach, L.H., Camper, A.K., Goslan, E.H., Parsons, S.A. and Xie, Y.F., (2010) Biodegradation of HAAs in Distribution Systems, WRF \#3122, Denver CO.

Kanokkantapong. V., Marhaba, T.F., Wattanachira, S., Panyapinyophol, B., and Pavasant, P., (2005) Interaction Between Organic Species in the Formation of Haloacetic Acids Following Disinfection. Journal of Environmental Science and Health Part A, 41:1233-1248

Kim, J., Chung, Y., Shin, D., Kim, M., Lee, Y., Lim, Y., and Lee, D. (2002) Chlorination by-products in surface water treatment process. Desalination 151 1-9

Koch, Inc., (2013) Koch Membrane Systems URL:

http://www.kochmembrane.com/Water-Wastewater/Municipal-Water/SurfaceWater.aspx

Lazarova, V., Savoye, P., Janex, M.L., Blatchley, E.R., and Pommepuy, M. (1999) Advanced Wastewater Disinfection Technologies: State of the Art and Perspectives Water Science and Technology Vol 40 No 4-5 pp 203-214 (C) IWA Publishing 1999 Layne, E. Spectrophotometric and Turbidimetric Methods for Measuring Proteins. Methods in Enzymology 3: 447-455. 1957.

Leenheer, J., (1981) Comprehensive Approach to Preparative Isolation and Fractionation of Dissolved Organic Carbon from Natural Waters and Wastewaters. Environ. Sci. Technol., 1981, 15 (5), pp 578-587

Marhaba, T.F., Pu, Y. and Bengraine, K. (2003) Modified dissolved organic matter fractionation technique for natural water. Journal of Hazardous Materials B101 (2003) 43-53

Marhaba, T. F., and Washington, M. B, (1998) Drinking water protection and byproducts: his-tory and current practice. Advances in Envi-ronmental Research. 2, 103115.

Mountain Empire Community College, (2011) URL:

http://water.mecc.edu/courses/ENV115/

Nakahara, M. (2002) “The Science of Color”, Baifukan p. 108 
Nikolaou, A., Golfinopoulos S., Lekkas T., Kostopoulou M. (2004) DBP levels in chlorinated drinking water: effect of humic substances. Environ Monit Assess 2004, 93(1):301-319

Qasim,S. R., Motley, E.M. and Zhu, G., (2000) "Water Works Engineering", Chiang, Patel and Yerby, Inc., Dallas, Texas.

Reckhow, D.A., Singer, P.C., Malcolm, R.L., (1990) Chlorination of humic materials Byproduct formation and chemical interpretations: Environmental Science and Technology, v. 24, p. 1655-1664.

Rook, J.J., (1977) Chlorination reactions of fulvic acids in natural waters: Environmental Science and Technology, v. 11, no. 5, p. 478.

Russell, C.G., Lawler, D.F., Speitel, G.E., and Katz, L.E. (2009) Effect of Softening Precipitate Composition and Surface Characteristics on Natural Organic Matter Adsorption. Environmental Science Technology, 43, 7837-7842

Slower (2006), URL: http://commons.wikimedia.org/wiki/File\%3ATitcurve_H2CO3.png

Steiner, C.S., (2007) A Brief History of Miasmic Theory URL:

http://www.carlsterner.com/research/files/History_of_Miasmic_Theory_2007.pdf

Stoscheck, CM., (1990) Quantitation of Protein. Methods in Enzymology. 182: 50-69.

Tosaka (2008), URL: http://commons.wikimedia.org/wiki/File\%3AElectric_doublelayer_(Stern's_model)_NT.PNG

Traina, S.J., Novak, J., and Smeck, N.E., (1990), An ultraviolet absorbance method of estimating the percent aromatic carbon content of humic acids: Journal of Environmental Quality, v. 19, p. 151-153

UNSW3004SepG23, (2013) URL:

http://commons.wikimedia.org/wiki/File\%3AFiltration_solute.png

U.S. Environmental Protection Agency (1992) Water Treatment Simulation Program User's Manual Version 1.21, EPA No. 811B92001.

U.S. Environmental Protection Agency (1999) Enhanced Coagulation and Enhanced Precipitative Softening Guidance Manual, EPA 815-R-99-012

U.S. Environmental Protection Agency (1999) EPA Guidance Manual, Alternative Disinfectants and Oxidants, EPA 815-R-99-0.14.

U.S. Environmental Protection Agency (2012)

URL:http://water.epa.gov/infrastructure/drinkingwater/pws/factoids.cfm 
U.S. Department of the Interior | U.S. Geological Survey (2014) URL:

http://water.usgs.gov/edu/earthwherewater.html

Valle-Delgado, J.J. (2013) Double Layer Forces and DLVO Theory URL: https://noppa.aalto.fi/noppa/kurssi/puu-0.3110/luennot/Puu0_3110_double_layer_forces_and_dlvo_theory.pdf

Venczel, L.V., Arrowood, M., Hurd, M., and Sobsey, M.D. (1997) Inactivation of Cryptosporidium parvum oocysts and Clostridium perfringens spores by a mixed-oxidant disinfectant and by free chlorine. Appl. Environ. Microbiol., 63:4:1598-1601.

Water Research Foundation URL:

http://www.waterrf.org/knowledge/dbps/FactSheets/DBP-ControlStrategiesFactSheet.pdf

Wisconsin Department of Natural Resources URL:

http://dnr.wi.gov/regulations/labcert/documents/training/cl2breakpoint-c.pdf

Xie, Y.F. (2004) Disinfection Byproducts in Drinking Water: Formation, Analysisand Control. Lewis Publishers: Boca Raton, Fl. 